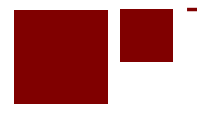

\author{
C E N T E R for \\ RETIREMENT \\ R E S E A R C H \\ at BOSTON COLLEGE
}

\title{
CAN BENEFITS AND WORK INCENTIVES COUNSELING BE A PATH TO FUTURE ECONOMIC SELF-SUFFICIENCY FOR SSI/SSDI BENEFICIARIES?
}

\author{
Zafar E. Nazarov
}

CRR WP 2013-17

Submitted: July 2013

Released: August 2013

\author{
Center for Retirement Research at Boston College \\ Hovey House \\ 140 Commonwealth Avenue \\ Chestnut Hill, MA 02467 \\ Tel: 617-552-1762 Fax: 617-552-0191 \\ http://crr.bc.edu
}

Zafar E. Nazarov is a research associate at Cornell University, Employment and Disability Institute and Institute for Compensation Studies. The research reported herein was pursuant to a grant from the U.S. Social Security Administration (SSA), funded as part of the Retirement Research Consortium (RRC). The findings and conclusions expressed are solely those of the author and do not represent the views of SSA, any agency of the federal government, the RRC, Cornell University, or Boston College. This research would not have been possible without the support of the New York State Education Department, Office of Adult Career and Continuing Education Services-Vocational Rehabilitation (ACCES-VR), the agency which provided data on SSI-SSDI beneficiaries served from 2003 to 2009.

(C) 2013, Zafar E. Nazarov. All rights reserved. Short sections of text, not to exceed two paragraphs, may be quoted without explicit permission provided that full credit, including $($ ) notice, is given to the source. 


\begin{abstract}
About the Steven H. Sandell Grant Program
This paper received funding from the Steven H. Sandell Grant Program for Junior Scholars in Retirement Research. Established in 1999, the Sandell program's purpose is to promote research on retirement issues by scholars in a wide variety of disciplines, including actuarial science, demography, economics, finance, gerontology, political science, psychology, public administration, public policy, sociology, social work, and statistics. The program is funded through a grant from the Social Security Administration (SSA). For more information on the Sandell program, please visit our website at: http://crr.bc.edu/about-us/grantprograms/stevenhsandell-grant-program-2/ send e-mail to crr@bc.edu, or call (617) 552-1762.
\end{abstract}

\title{
About the Center for Retirement Research
}

The Center for Retirement Research at Boston College, part of a consortium that includes parallel centers at the University of Michigan and the National Bureau of Economic Research, was established in 1998 through a grant from the Social Security Administration. The Center's mission is to produce first-class research and forge a strong link between the academic community and decision-makers in the public and private sectors around an issue of critical importance to the nation's future. To achieve this mission, the Center sponsors a wide variety of research projects, transmits new findings to a broad audience, trains new scholars, and broadens access to valuable data sources.

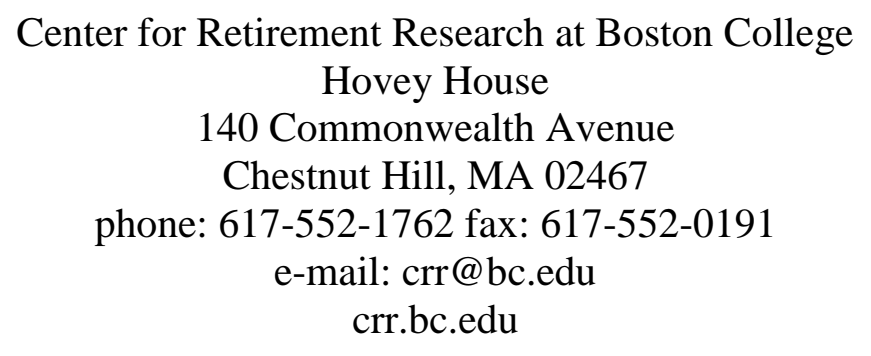

Affiliated Institutions:

The Brookings Institution

Massachusetts Institute of Technology

Syracuse University

The Urban Institute 


\begin{abstract}
In this paper, we estimate the effect of benefits and work incentives counseling services on the labor market outcomes of Supplemental Security Income (SSI) and Social Security Disability Insurance (SSDI) beneficiaries participating in the vocational rehabilitation (VR) programs between 2003 and 2009 in New York State. By explicitly controlling for non-random selection of beneficiaries into the services using the propensity score matching and instrumental variable methods, the paper contributes to the literature by providing more precise estimates of causal relationships between benefits and work incentives counseling services and several labor market outcomes of beneficiaries. We find that the effect of benefits and work incentives counseling on the probability of successful case closure can be positive, but in certain cases is not statistically significant. At the same time, the estimates of the effects of benefits and work incentives counseling on earnings and working hours at closure are positive and substantial in magnitude. The provision of benefits and work incentives counseling can be considered as a first and important step toward achieving financial independence for the large group of SSI/SSDI beneficiaries with strong employment goals.
\end{abstract}




\section{Introduction}

The main objective of this study is to understand the effectiveness of benefits and work incentives counseling services in terms of their impact on successful case closure, weekly earnings, and workings hours of Supplemental Security Income (SSI) and Social Security Disability Insurance (SSDI) beneficiaries participating in the state vocational rehabilitation program in New York State between the years of 2003 and 2009. Benefits and work incentives counseling services are defined as

a set of benefits and work incentives counseling strategies, services, and supports that seek to promote work preparation, attachment, and advancement focusing on the enhancement of self-sufficiency and independence of individuals with disabilities who receive disability benefits and other public entitlements through informed choice, which may result in decreased reliance on public benefit programs and increased financial well-being. (Golden, et al., 2000)

The main mission and purpose of these services is to assist SSI/SSDI beneficiaries who have a desire to work in finding and maintaining employment, and to permanently leave the Social Security benefit rolls in the future (Kregel, 2009).

Several studies in the past have attempted to quantify the impact of benefits and work incentives counseling services on individual's earnings and employment, utilization of work incentives embedded into the SSA disability programs, and reduction and termination of SSI/SSDI benefits. The findings of these studies suggest that the beneficiaries who receive benefits and work incentives counseling services achieve significantly greater improvements in earnings (Tremblay et al., 2004 and 2006; and Delin et al., 2010), employment (Livermore and Prenovitz, 2010; Peikes, Moreno, and Orzol, 2012), utilization of work incentives (Livermore and Prenovitz, 2010), and transitioning off the benefits rolls (Livermore, Prenovitz, and Schimmel, 2011). However, the methods of measuring the effect of benefits and work incentives counseling services in previous studies have one serious limitation; previous studies, with the exception of Peikes, Moreno, and Orzol (2012), do not account for non-random selection of beneficiaries into the services.

Specifically, one of the significant challenges of any causal inference using nonexperimental data is to estimate the "true" treatment effect. The main issue with nonexperimental data is that there are substantial problems with identifying observations for a control group - those individuals who were not chosen for treatment. Though data generated in 
the real world setting provide observations for both the group of individuals who were selected or selected themselves into a treatment group, and for the group of individuals who were not selected for treatment, the representatives of the control group cannot be used as counterfactuals to the treatment group observations. Therefore, additional steps should be taken to construct the proper control group, using more advanced econometric techniques such as propensity score matching (PSM) or an instrumental variable (IV) approach. In the context of benefits and work incentives counseling services, propensity score matching has only been used in a study by Peikes, Moreno, and Orzol (2012). To date, our study appears to be the only study in the literature that adopts the instrumental variable approach to evaluate the effectiveness of benefits and work incentives counseling services.

There are pros and cons to these methods. The PSM method helps to create the counterfactuals for the observations of the treatment group based on a propensity score (Dehejia and Wahba, 2002). The propensity score is a function of certain variables which characterize the actual selection mechanism. A failure to control for any important variable would make this approach unattractive relative to the alternative approaches. Peikes, Moreno, and Orzol (2012) is the only study in the benefits and work incentives counseling literature which used the PSM method to evaluate the effectiveness of these services. After comparing results received using the PSM method with the results received from a randomized control trial, they came to the conclusion that the selection of beneficiaries into the services could be partially characterized by some variables not included in the calculation of propensity scores. Specifically, if a highly motivated beneficiary has a higher propensity of being selected to these services, then any observed improvement in beneficiary's employment outcomes after the intake of services might be the result of increased motivation towards work, and not necessarily due to the receipt of benefit and work incentives counseling services. The variable related to an individual's motivation toward work was not the part of control variables. In this case, to evaluate benefits and work incentives counseling services, one has an option either to run a randomized control trial as done by Peikes, Moreno, and Orzol (2012) or conduct a quasi-experimental study using the IV approach.

The main rationale behind the IV approach is simple. A researcher should identify a single variable or set of variables which have the potential to explain variation in selection into the services and do not have a direct impact on the outcomes of beneficiaries. We use the 
identification strategy similar to one proposed by Aakvik, Heckman, and Vyltacil (2005) in their evaluation of the effectiveness of the Norwegian Vocational Rehabilitation Program. A possible instrumental variable that may have a direct impact on the receipt of benefits and work incentives counseling services with no impact on the outcomes of beneficiaries could be the percentage of beneficiaries in local district offices who do not receive these services. State Vocational Rehabilitation Programs are administered at the state level through a federal partnership with the Rehabilitation Services Administration, and typically, each state is broken down into regional or district offices for execution of the state program. Using this variable as an instrument, we explicitly assume that the receipt of benefits and work incentives counseling services can be directly impacted by a district office's capacity to provide such services. Holding everything else equal, two statistically equivalent beneficiaries residing in different district offices may have disparate employment outcomes solely due to differences in districts' capacities to provide benefits and work incentives counseling services to SSI/SSDI beneficiaries.

The use of districts' capacities in providing benefits and work incentives counseling services to SSI/SSDI beneficiaries in estimating the effectiveness of the latter services has a direct policy implication. Kregel (2009) points out that, based on the National Beneficiary Survey (NBS), about 44 percent of SSI/SSDI beneficiaries consider employment in the next five years as their prime goal. It is essential to provide employment-related services, including benefits and work incentives counseling services, to a work-oriented beneficiary at the point at which the beneficiary has made the important commitment to work. There is empirical evidence that, currently, benefits and work incentives counselors are overwhelmed by the number of beneficiaries who are seeking services. Specifically, according to Kregel (2009), for a single certified benefits and work incentives counselor there are more than 10,000 beneficiaries and the system needs at least 1,600-1,800 additional highly trained counselors nationwide. Our identification strategy should allow us to quantify the relationship between the percentage of beneficiaries in local districts who do not receive benefits and work incentives counseling services and labor market outcomes of all beneficiaries participating in the VR programs. Assuming that an increase in the number of benefits counselors in the local district would increase the percentage of beneficiaries who received these services, we can quantify how the hypothetical increase in the number of benefits and work incentives counselors would affect the employment outcomes of SSI/SSDI beneficiaries. 
Our results show that benefits and work incentives counseling services may have some modest impact on the probability of successful case closure for SSI/SSDI beneficiaries. This implies that benefits and work incentives counseling services alone may encourage participation in competitive employment. At the same time, the services appear to substantially improve working hours and weekly earnings of the segment of the population with severe limitations and impairments who receive SSI/SSDI benefits. Specifically, benefits and work incentives counseling services appear to increase working hours by 31 percent and weekly earnings of SSI/SSDI beneficiaries by 40 percent. These findings reinforce several important assumptions regarding benefits and work incentives counseling services. First, benefits and work incentives counseling services fortify and move beneficiaries toward greater economic self-sufficiency for work-oriented SSI/SSDI beneficiaries who have a strong desire to return to work. Benefits and work incentives counseling appears to support state vocational rehabilitation programs in better serving the SSI/SSDI population, and making greater progress toward their key performance indicators established by the Rehabilitation Services Administration. These services also result in a greater likelihood that state vocational rehabilitation programs will more likely receive traditional cost reimbursement payments from SSA. Finally, benefits and work incentives counseling services appear to be an important catalyst to SSI/SSDI beneficiaries in working toward their full potential and employment capacities.

\section{Background}

The objectives of benefits and work incentives counseling services are multi-faceted (Golden et al., 2000; Kregel, 2009; Kregel and O'Mara, 2011). The first and the most important objective is to assist SSI/SSDI beneficiaries in understanding the impact of potential earnings on their public entitlements, by presenting a series of possible pathways to employment and economic self-sufficiency. Hennessey and Muller (1995) point out that many beneficiaries have considerable motivation to return to work and they cite two main reasons based on surveys of beneficiaries. First, 81 percent of working beneficiaries recognize that the inability to meet their daily financial needs was a main factor in the decision-making process to return to work. Second, for 58 percent of working beneficiaries, one of the main reasons to return to work was simply their desire to work. This implies that many beneficiaries have the motivation and financial incentives to return to work, however, they may lack a good planning strategy for how to effectively transition from reliance on public entitlements to financial independence. Kregel 
and O'Mara (2011) assert that a good employment and economic plan can be a pathway for beneficiaries to successfully achieve their self-chosen lifestyle goals. Thus, a well-developed employment and economic plan can be an essential step toward future economic self-sufficiency, and meaningful and prolonged employment for work-oriented beneficiaries.

The second objective of benefits and work incentives counseling services is to provide information on work incentives and employment supports which may be available through the various public entitlements they receive, as well as available employment options in the local market. Livermore, Roche, and Prenovitz (2009) indicate that one of the potential barriers for employment among beneficiaries could be that many lack an understanding of all the employment-related supports and resources embedded and available in the system. Furthermore, many beneficiaries don't have accurate information on all available jobs in their local communities. In many instances, beneficiaries lack knowledge on retraining opportunities provided through workforce development and vocational rehabilitation programs. The latter should enable them to avoid any future prospects of underemployment and working for lowwages. Finally, beneficiaries may face difficulties with accessing high quality job placement and employment support services. Gaining a better understanding of employment options and supports could improve beneficiaries' prospects of obtaining and maintaining employment and reaching income levels specified in their individualized goals and plans.

It is a well-known fact that many SSA beneficiaries have only a murky understanding of the way employment may impact their benefits and health care coverage (Thornton, et al., 2007). SSA disability programs offer a number of employment support provisions intended to promote employment through providing vocational rehabilitation services and other employment-related supports to work-oriented beneficiaries. Most importantly, some automatic work incentive provisions, which are embedded into the SSA disability programs, enable beneficiaries to maintain their cash and health care coverage even in the case of full-time employment with substantial earnings. To improve the knowledge of beneficiaries, benefits and work incentives counseling services provide individualized information on all work incentive and return-to-work provisions considering personal circumstances related to individual's interests, personal goals, support needs, and portfolio of public entitlements they may receive.

The provision of long-term assistance and support to beneficiaries is a recent value-added element of benefits and work incentives counseling services. Due to a failure of SSA to develop 
adequate and comprehensive past work histories of working beneficiaries, many beneficiaries receive SSI/SSDI overpayments, leading to their immediate withdrawals from the labor force (Kregel, 2009). Benefit and work incentives counseling may help to assist beneficiaries to keep track of their earnings more accurately and to plan for any possibility of overpayment due to fulltime employment. Furthermore, Golden et al. (2000) recognize that "monitoring and follow-up" is a key element to successfully integrate the beneficiaries into a competitive environment. Longterm assistance is especially important at the early stages of transitioning to economic selfsufficiency. The focus of pro-active monitoring and follow-up is "regular intermittent contact with individuals, consistent communication, crisis management, information and referral, problem solving, and advocacy" (Golden et al, 2000).

The pivotal element of benefits and work incentives counseling services are practitioners who interact face-to-face with beneficiaries, and whose understanding of all details of welfare, public entitlements, and health care systems, and ability to translate it to a quite vulnerable audience, have a direct impact on employment outcomes of the beneficiaries. The last 30 years have shown a tremendous expansion of benefits and work incentives counseling services in the United States - promulgated in part by the growth in integrated employment service delivery and increased national emphasis on an 'employment first' agenda. The emerging field of benefits and work incentives counseling services has grown out of existing professional roles and functions of practitioners in diverse fields. Today, the field of professionals practicing benefits and work incentives counseling represent different fields, such as rehabilitation counseling, transition planning, advocate and peer counseling, supported employment, and vocational evaluation (Golden, et al., 2000). While these practitioners often do not focus solely on the delivery of benefits and work incentives counseling, they perform valued work within the context of their existing responsibilities. With the passage of the Ticket to Work and Work Incentives Improvement Act of 1999, a new era began to emerge - dedicated to the establishment of a national network of full-time benefits and work incentives counseling practitioners sponsored by the SSA. Initially referred to as the Benefits Planning and Assistance Programs (BPAO), and currently referred to as the Work Incentive Planning and Assistance Programs (WIPA), this national network has continued to evolve and hone the field of benefits and work incentives counseling.

There are certain skills and background that a counselor should acquire before practicing 
benefits and work incentives planning and assistance. Specifically, the counselor should have a good understanding of the details of SSA disability and other federal and state welfare programs, all available work incentives embedded into welfare and public entitlement programs, the complex interaction of public and private health insurance programs, and the intricacies of the local labor market (Kregel, 2009). Besides technical knowledge about the welfare and health care systems, the counselors should possess certain counseling skills (Golden et al, 2000; Kregel, 2009) to be able to effectively "glean information, share expertise, support problem solving, provide advocacy, foster the development of self-determination, and support informed choice, and decision making" (Golden, et al., 2000). Finally, communication skills including receptive listening, values-free communication, or expressive communication are other imperative elements of benefits and work incentives counseling (Golden, et al., 2000).

\section{Literature Review}

There is only a dearth of literature on the effectiveness of benefits and work incentives counseling services. The most investigated outcome in the literature as shown in Table 1 is the earnings of SSI/SSDI beneficiaries after the receipt of benefits and work incentives counseling services (Tremblay, et al., 2004; Tremblay, et al, 2006; Delin, Hartman, and Sell, 2010; Gruman et al., 2010; Livermore and Prenovitz, 2010; Livermore, et al., 2011; and Peikes et al., 2012). In many instances, the beneficiaries' earnings are observed for the certain period of time before the receipt of services and for the same period of time after by mainly linking individual level information with the Unemployment Insurance (UI) files. The latter strategy enabled researchers to observe the longitudinal evolution of individuals' earnings even after their separation from the vocational rehabilitation program or SSI/SSDI. Further, the earnings of the beneficiaries who received benefits and work incentives counseling services are compared with the earnings of certain groups of beneficiaries who, mainly, did not receive the service.

As the second column of Table 2 shows, almost all studies found some positive association between the future earnings and receipt of benefits and work incentives counseling services. However, the magnitude of this association varies widely across studies. Tremblay, et al. (2004) found that the earnings gap between recipients of services and other non-recipients can be between $\$ 190$ - $\$ 220$ per quarter. Restricting their attention to beneficiaries with psychiatric disabilities, Tremblay, et al. (2006) ended up with a larger gap between two segments of the population, \$318 per quarter. Separating those who received only benefits and work incentives 
counseling services from those who received them in combination with vocational rehabilitation services, Gruman, et al. (2010) found that after the first quarter of intervention, the second group of beneficiaries experienced a $\$ 400$ improvement in their earnings relative to non-recipients earnings, which is twice larger than the improvement in earnings for the first group of beneficiaries. It should be further noted that, despite a substantial gain in earnings after the first quarter of intervention, both groups experienced a decline in their earnings, reaching the baseline earnings after five quarters. Comparing the annual earnings of two groups of beneficiaries recipients and non-recipients of benefits and work incentives counseling services - Livermore and Prenovitz (2010) reported only a \$336 difference in annual earnings. In a recent study, Peikes, et al. (2012) show that the earnings of beneficiaries may actually have declined after their receipt of services compared to the non-recipient counterparts.

Two studies explored the association of earnings of beneficiaries with benefits and work incentives counseling services in the intensive margin (hours of counseling services). Livermore et al. (2011) shows that, relative to those who received less than three hours of benefits and work incentives counseling services, recipients of three to six hours have a 31 percent higher chance of experiencing an increase in future earnings and recipients of above six hours of services have a 60 percent higher chance of experiencing an increase in future earnings. Delin, Hartman, and Sell (2010) break down the recipients into three groups by total hours of benefits and work incentives counseling services received by beneficiaries: the high "dosage" group includes beneficiaries who received one-half standard deviation above the mean, the middle "dosage" group includes beneficiaries who received within one-half standard deviation of the mean and low "dosage" group includes beneficiaries who received one-half standard deviation below the mean or who did not receive these services at all. Using this grouping strategy, the authors arrive at the conclusion that relative to the lowest dosage group, the medium dosage group's mean earnings increased by $\$ 34.40$ per quarter and the high dosage group's mean earnings increased by $\$ 68.30$ per quarter.

Along with earnings, employment has been another outcome of interest of the studies which explored the effectiveness of benefit and work incentives counseling services (Delin, Hartman, and Sell, 2010; Livermore and Prenovitz, 2010; Livermore, Prenovitz, and Schimmel, 2011; and Peikes, Moreno, and Orzol 2012). All these studies report the existence of a positive association between benefits and work incentives counseling services and employment rate of 
SSI/SSDI beneficiaries. In the year of intake of benefits and work incentives counseling services, Peikes, Moreno, and Orzol (2012) demonstrates that the users of services have a higher employment rate by 9-14 percentage points. The effect of the services may have a long-lasting impact on beneficiaries' employability. Compared to all beneficiaries, as Livermore and Prenovitz (2010) show, users of benefits and work incentives counseling services have a 34 percentage points higher likelihood of being involved in gainful activities three years following the year of intake of the services. As some studies show, the intensity of benefits and work incentives counseling may have also a positive impact on the beneficiaries' employment rate. For example, Delin, Hartman, and Sell (2010) demonstrate that relative to the lowest dosage group, the medium and high dosage groups' employment rates are 1.1 and 2.2 percent higher, respectably. Livermore, Prenovitz, and Schimmel (2011) also show that the effectiveness of the services increases with the hours of services. Relative to those who received less than three hours of the services, for those who received more than six hours of the services, the employment rate was 39 percent higher in 2010.

The utilization of work incentives embedded into the SSA disability program system and SSI/SSDI benefits termination or reduction is among the other outcomes of SSI/SSDI beneficiaries which have been investigated, in terms of their associations with benefits and work incentives counseling services. It is not surprising that studies find that the users of benefits and work incentives counseling services more frequently utilize the automatic work incentive provisions of DI and SSI programs - such as the Trial Work Period (TWP), Extended Period of Eligibility (EPE) or sections 1619(a) and (b) allowing the user to maintain cash and health insurance benefits while working. Specifically, Livermore and Prenovitz (2010) show that the utilization of TWP and EPE was 21 percent and 11 percentage points higher for the users of benefits and work incentives counseling services compared to the non-users of these services. Beneficiaries who received benefit and work incentives counseling services are about 20 percentage points more likely to use the work incentive provision known as 1619(b), which allows them to maintain Medicaid coverage while working. The participation in non-automatic work incentive provisions such as Ticket to Work (TTW) is also higher for the users of benefits counseling services. About 19 percent of the users of benefits and work incentives counseling services utilized their tickets in exchange for employment-related services, compared to 2 percent for the non-users (Livermore and Prenovitz, 2010). 
Livermore and Prenovitz (2010) show that the fraction of beneficiaries who left the benefits rolls due to work for at least one month during their study period is higher for the users of benefits and work incentives counseling services. Approximately 13.7 percent of the recipients of services were off the disability rolls due to work, which is about 8 percentage points higher compared to all beneficiaries. Surprisingly, the duration of being off the benefits rolls due to work is not different across these two groups and takes 13-14 months on average. Finally, the results of the multivariate analysis conducted by Livermore, Prenovitz, and Schimmel (2011) demonstrate that, of the factors associated with at least one month of nonpayment status following a suspension or termination due to work, users who received more than six hours of benefits and work incentives counseling services had a 60 percent higher chance of experiencing nonpayment status and being suspended from benefits.

We extend the current literature on effectiveness of benefit and work incentive counseling services in a quite important direction. In our empirical models, we explicitly control for non-random selection of beneficiaries into the services by both observed and unobserved factors. The latter issue has been, in many instances, ignored by previous studies. The only study in the literature that has recognized the importance of accounting for the non-random selection issue in the understanding of the relative effectiveness of benefits and work incentive counseling services is the study by Peikes, Moreno, and Orzol (2012). However, the identification strategy employed by the authors of the study precludes any possibility of selection into the services by factors unobserved to researchers (for example, motivation). One of the identification strategies used in this study explicitly addresses this issue and then allows us to simulate the changes in employment outcomes of beneficiaries due to the changes in the district's capacity to provide these services.

\section{Methods}

We use two approaches to explore the causal link between benefits and work incentives counseling services and the selected employment outcomes of SSI/SSDI beneficiaries: propensity score matching (PSM) and the instrumental variable (IV) approaches. Each approach has a distinct identification strategy and, as a result, the interpretation of the main parameter of interest (the relationship between benefit counseling services and an employment outcome) varies drastically across the methods. As we show in this section, PSM provides an estimate of the average treatment effect on the treated (ATET) while IV provides an estimate of local 
average treatment effect (LATE). Notwithstanding the fact that the estimates for the primary parameter of interest aren't quite comparable across the two statistical methods, we still choose to compute both estimates to gain a better understanding of the effectiveness of benefit counseling services. Using the results of the IV regression, we further intend to simulate the changes in employment outcomes of beneficiaries due to the exogenous changes in the instrumental variable. Specifically, we would like to quantify the sensitivity of employment outcomes to the changes in district capacity to provide benefit counseling services to SSI/SSDI beneficiaries.

Suppose, we observe $\left(Y_{i}, X_{i}, B_{i}\right)$ where $i=1, \ldots, N, N$ is the number of SSI/SSDI beneficiaries and $Y_{i}$ is any employment outcome of the typical SSI/SSDI beneficiary. The outcome can be associated with socio-demographic and environmental characteristics included in vector, $X_{i}$, and a binary variable $B_{i}$ indicating the receipt of benefits and work incentives counseling services. To justify the use of the PSM approach, we first assume that vector $X_{i}$ contains all the variables explaining the selection mechanism into the benefit counseling services. Thus, a typical beneficiary should face two potential employment outcomes depending on his/her decision to participate in benefit counseling.

$$
Y_{i}= \begin{cases}Y_{1 i} & \text { if } B_{i}=1 \\ Y_{0 i} & \text { if } B_{i}=0\end{cases}
$$

As a result, the actual observed outcome of the SSI/SSDI beneficiary is the combination of the two potential outcomes corresponding to each alternative.

$$
Y_{i}=Y_{0 i}+\left(Y_{1 i}-Y_{0 i}\right) B_{i}
$$

Then, given $Y_{1 i}$ and $Y_{0 i}$, the average treatment effect can be described as the combination of two terms.

$$
\begin{aligned}
\Delta=E\left[Y_{i} \mid X_{i}, B_{i}=1\right]-E\left[Y_{i} \mid X_{i}, B_{i}=0\right] & =E\left[Y_{1 i}-Y_{0 i} \mid X_{i}, B_{i}=1\right]+ \\
& +\left\{E\left[Y_{0 i} \mid X_{i}, B_{i}=1\right]-E\left[Y_{0 i} \mid X_{i}, B_{i}\right]=0\right\}
\end{aligned}
$$

The first term is the ATET. The second term is a bias term which would equal zero, conditional on a set of observed characteristics given by $X$, and the assignment to benefit counseling services is random. After dropping the second term (assuming that all variables affecting the individual's decision to receive benefit counseling services are included in $X$ ), the ATET can be expressed as the expectation of differences of the expected outcomes in the case of receiving and not 
receiving benefit counseling services.

$\Delta^{A T E T}=E\left[Y_{1 i}-Y_{0 i} \mid X_{i}, B_{i}=1\right]=E\left[\left\{E\left[Y_{1 i} \mid X_{i}, B_{i}=1\right]-E\left[Y_{0 i} \mid X_{i}, B_{i}=0\right]\right\} \mid B_{i}=1\right]$

Further, instead of controlling for all elements of $X$, the propensity score theorem allows one to compute ATET by simply controlling for a single covariate $p\left(X_{i}\right)=E[B i \mid X i]=P\left[B_{i}=1 \mid X_{i}\right]$. The term $p\left(X_{i}\right)$ is known as a propensity score because it represents an actual score of receiving benefit counseling services. The value of the propensity score for each beneficiary can be easily computed using conventional probit or logit regressions, controlling for a set of covariates which

have a direct impact on the decision to receive benefit counseling services. The following condition provides condition (4) with respect to this propensity score term.

$$
\begin{aligned}
\Delta^{A T E T}=E\left[Y_{1 i}-Y_{0 i} \mid X_{i}, B_{i}=\right. & 1]=E\left[\left\{E\left[Y_{1 i} \mid p\left(X_{i}\right), B_{i}=1\right]-E\left[Y_{0 i} \mid p\left(X_{i}\right), B_{i}=0\right]\right\} \mid B_{i}=1\right]= \\
= & E\left[\frac{\left(B_{i}-p\left(X_{i}\right)\right) Y_{i}}{\left(1-p\left(X_{i}\right)\right) P\left(B_{i}=1\right)}\right]
\end{aligned}
$$

To substantiate our application of the IV approach, we use the simple linear formulation of the employment outcome and its relationship with the observed characteristics included in vector $X_{i}$, an indicator of participation in benefit counseling services, $B_{i}$ and an error term $\square_{\mathrm{i}}$. Now, we can relax the assumption that $X_{i}$ contains all elements of the decision-making process of pursuing benefit counseling services and outcome formation. If any important element of the decision-making process and outcome formation is missing in the linear formulation of the outcome, then this element would be captured by term $\square_{i}$. The second term in the third condition is no longer zero, and as a result, the conventional OLS regression or PSM method would contain the bias term in the estimate of $\Delta$.

$Y_{i}=X_{i} \alpha+\Delta B_{i}+\varepsilon_{i}$

Suppose the decision to participate in the benefit counseling program depends on a single variable in $Z$, known as an instrumental variable.

$B_{i}^{*}=\gamma_{0}+\gamma_{1} Z_{i}+v_{i}$,

In the above expression, $B_{i}^{*}$ is a propensity to receive benefit counseling services, which is a latent variable. However, data allows us to identify $B_{i}$, which is an indicator of the actual receipt of benefit counseling services, 


$$
B_{i}=\left\{\begin{array}{lll}
0 & \text { if } & B_{i}^{*} \leq 0 . \\
1 & \text { if } & B_{i}^{*}>0
\end{array}\right.
$$

Further, suppose that $Z^{\prime}=Z+\square \square$ and note that $E\left[B_{i} \mid X_{i}, B_{i}\left(Z_{i}\right)\right]=\operatorname{Pr}\left[B_{i}\left(Z_{i}\right)=1\right]$, taking the expectation of condition 7 separately for values $Z$ ' and $Z$, we end up with the following two conditional expectations of $Y_{i}$.

$$
\begin{aligned}
& E\left[Y_{i} \mid X_{i}, B_{i}\left(Z_{i}\right)\right]=X_{i}^{\prime} \alpha+\Delta \operatorname{Pr}\left[B_{i}(Z)=1\right] \\
& E\left[Y_{i} \mid X_{i}, B_{i}\left(Z_{i}^{\prime}\right)\right]=X_{i}^{\prime} \alpha+\Delta \operatorname{Pr}\left[B_{i}\left(Z_{i}^{\prime}\right)=1\right]
\end{aligned}
$$

The subtraction of condition (9) from condition (10) and solving for $\Delta$, we receive another expression identifying the effect of benefit counseling services on employment outcomes. It is straightforward to verify that the magnitude of the effect now depends on the choice of the instrument and the size of the segment of the population which the instrument actually induces to change the behavior related with the receipt of benefits counseling and work incentive services; therefore, this effect, received using the IV approach, is known as the LATE.

$$
\Delta^{L A T E}=\frac{E\left[Y_{i} \mid X_{i}, Z_{i}^{\prime}\right]-E\left[Y_{i} \mid X_{i}, Z_{i}\right]}{\operatorname{Pr}\left[B_{i}\left(Z_{i}^{\prime}\right)\right]-\operatorname{Pr}\left[B_{i}\left(Z_{i}\right)\right]}
$$

A simple comparison of expressions (5) and (11) reveals that the PSM and IV approaches identify quite different effects for the association between benefit counseling services and any given employment outcome of SSI/SSDI beneficiaries. Most importantly, the consistency of these effects depends on different assumptions. The PSM estimator assumes that for every element of $X$ there is a positive probability of non-participation in benefit counseling services. Roughly speaking, the control and treated populations can be stratified by $X$ and each stratum contains representatives of both populations. If in the process of matching, one fails to produce a good number of matches, then that would indicate that the latter condition, known as the overlap condition, hasn't been satisfied. Finally, the PSM estimator assumes that the factors that are not observable in the dataset play no role in selection to the treatment and in determination of the outcome.

The latter restrictive assumption can be relaxed by the instrumental variables approach. However, the consistency of the IV approach depends on two crucial assumptions. First, the instrumental variable should in no way be directly impacting the employment outcome of the beneficiary. Second, the instrumental variable should be strongly correlated with the decision to 
participate in benefit advisement and planning programs. Although the first assumption is not directly testable, a conventional t-test in the $B_{i}$ against $Z_{i}$ regression should enable us to make a compelling judgment on the validity of the second assumption for the chosen instrument. Along with relaxing the restrictive assumption on completeness of vector $X$, the main benefit of the IV approach is that it allows one to simulate the changes in the employment outcome due to changes in $Z_{i}$. Specifically, using estimates of the IV regression, we can predict the outcome for different values of $Z_{i}$ for each beneficiary and then compute the average response of the population to the changes in the instrumental variable. The latter should allow us to project that any improvement in employment among beneficiaries is due to improvement in district capacity to provide benefit counseling services.

Finally, within our empirical investigation of the relationship between benefits and work incentives counseling services and weekly earnings or working hours at closure, the censoring nature of the latter variables should be adequately addressed as well. In reality, one would observe earnings and working hours only on those beneficiaries who are successfully employed at the time of their case closure by the vocational rehabilitation system. The employment outcomes of unsuccessfully rehabilitated beneficiaries are not observable for researchers, either due to the inability to locate the beneficiary or his/her actual non-employment status. As a result, earning and working hour information is censored at zero for those who were unsuccessfully rehabilitated, leading to the statistical issue also known in the literature as the sample selection or censoring issue. In the PSM method, we ignore any censoring issue by constraining our attention to only successfully rehabilitated consumers. As a result, the PSM results can be biased due to both the censoring issue and non-random selection by unobserved factors. However, within the instrumental variable framework, we explicitly attempt to address both statistical problems by jointly estimating specifications of earnings or working hours along with the probability of successful case closure and selection into the services. In Appendix I, we specify our empirical model in more detail, addressing both the censoring and selection issues.

\section{Data}

The Case Administration Management System (CaMS) of New York State Adult Career and Continuing Education Services (ACCES-VR) is the main data source used in this study. CaMS is an administrative case management data system used across all ACCESS-VR district offices to track the process of rehabilitation for individuals with disabilities who have applied for 
vocational rehabilitation services in New York State. Along with information on the rehabilitation process, CaMS captures detailed information on socio-demographic characteristics of individuals, including SSI and SSDI program participation. Furthermore, certain employment indicators are available in CaMS at the time of application and closure, including information on weekly working hours, earnings for working individuals, and whether employment was in an integrated setting. Finally, CaMS includes detailed information on the list of services incorporated in the Individual Plan of Employment (IPE) with detailed information on duration and total cost of each service.

For this study, we used six years of CaMS data, restricting our sample to SSI/SSDI beneficiaries for whom the IPE was fully developed and initiated between October 2003 and October 2009. We also restricted our sample to SSI/SSDI beneficiaries who were on the benefit rolls at application. In only a few instances, the consumers reported receiving SSI/SSDI benefits at closure, while reporting zero benefits at the time of the application. For the sake of simplicity, we decided to drop such cases from our sample. Using the above two sample selection criteria, we ended up with the sample of 38,125 SSI/SSDI beneficiaries, among whom only about 622 beneficiaries received benefits and work incentives counseling services according to the developed IPEs.

Table 3 provides definitions for key dependent, instrumental, and control variables used in this study. The key dependent variables, which we recognize as employment outcomes in the text, are indicators of successful case closure, amount of weekly earnings, and working hours. The individual case is considered a successfully closed when the individual is employed for a consecutive 90 days in a competitive employment setting. Weekly earnings of the individual at closure include all income from wages, salaries, tips, and commissions before any payroll deductions. Finally, working hours are the number of hours the individual worked for earnings in a typical week at the time of the case closure.

The key instrumental variable used to identify the effect of benefits and work incentives counseling services on the key employment outcomes is the percentage of beneficiaries in the district office who do not receive benefits and work incentives counseling services. This is in the line of the identification strategy used by Aakvik, Heckman, and Vyltacil (2005) in their evaluation of the effectiveness of the Norwegian Vocational Rehabilitation Program. Figure 1 depicts the percentage of SSI/SSDI beneficiaries who received benefits and work incentives 
counseling services in the different district offices of the New York State ACCES-VR service delivery structure. The largest fraction of SSI/SSDI beneficiaries receiving benefits and work incentives counseling services appears to be in the Rochester district office. Slightly less than 9.5 percent of all beneficiaries who participated in the vocational rehabilitation process were exposed initially to benefits and work incentives counseling services. All other district offices provided these services to a substantially lower fraction of beneficiaries. The second- and thirdranked district offices are Mid-Hudson and Southern Tier, which provide services only to 2.77 percent and 2.63 percent, respectively, of beneficiaries who participated in the rehabilitation process. The next two district offices, Albany and Buffalo, provide services only to 1.81 percent and 1.73 percent of beneficiaries. The rest of the New York State VR district offices either provided benefits and work incentives counseling services to less than 1 percent of beneficiaries or did not provide them at all. All these statistics indicate a substantial district-level variation in the receipt of benefits and work incentives counseling services, implying that the receipt of benefit and work incentives counseling services can be directly impacted by a district's capacity to provide such services. Assuming that the district capacity to provide benefit counseling services is unrelated to the distribution of highly work-oriented beneficiaries across district offices, we can use the information on the percentage of beneficiaries in local districts who do not receive these services as an appropriate exclusion restriction in the individual's propensity to receive benefit counseling services.

Table 3 also provides information on the key control variables used in our empirical investigation. Along with the typical demographic variables such as age, gender, race, marital status, and education, we also control for the indicators of primary disability, living arrangement, primary source of support, the presence of secondary disability, veteran status, receipt of SSI benefits or jointly with SSDI benefits, and finally, the level of the county unemployment rate at the time of separation from the VR system. We conjecture that all these variables, in certain ways, contribute to the beneficiaries' decisions to receive benefits and work incentives counseling services and also how they directly impact the beneficiaries' employment outcomes after receiving other VR services.

Table 4 provides descriptive statistics on the key control and employment outcome variables used in this study. The descriptive analysis is broken down by the receipt of benefits counseling services to demonstrate that selected characteristics explain the selection mechanism 
to benefits and work incentives counseling services and consecutive employment outcomes. Table 4 shows that about 5 percent of the beneficiaries have sensory/visual impairments, 22 percent of the beneficiaries have physical disabilities, and 72 percent of the beneficiaries have a variety of mental disorders. However, our results indicate that the beneficiaries with sensory/visual impairments and mental health disorders are less likely to refer themselves to the benefits counseling services, compared to the beneficiaries with physical disabilities. The descriptive analysis shows that 59 percent of the beneficiaries in the sample have secondary disabling conditions and also have a higher propensity to receive benefits and work incentives counseling services compared to the beneficiaries with single disabling conditions. That may imply that beneficiaries with more than one disabling conditions preselect themselves into the services. Only 12 percent of the beneficiaries report having a legal spouse; among recipients of benefits and work incentives counseling services, married beneficiaries represent 16 percent of the sample. Although, in the whole sample, 56 percent of the beneficiaries are males, among recipients of benefit counseling services only 51 percent of the beneficiaries represent this gender group, suggesting that males are less likely to seek these services. Only 3 percent of the beneficiaries are former members of the armed forces and the descriptive analysis shows that veteran status is not a factor in the selection process for the service. Surprisingly, the recipients of benefits counseling services reside in areas with higher unemployment than their non-recipient counterparts. This suggests that a more rigid labor market conditions induce beneficiaries to seek assistance services, such as benefits planning.

Resulting analysis of our sample shows that 60 percent of the beneficiaries receive cash and in-kind benefits through SSI and 14 percent of the beneficiaries receive benefits through both SSI and SSDI. The participation in one of the means-tested welfare programs, SSI, is indicative of limited household income and very low earning capacity in the labor market of these beneficiaries. As a result, it is not surprising that this segment of the population appears less likely to seek benefits and work incentives counseling services to transition off the benefits rolls. Although all beneficiaries in the sample receive cash benefits from SSDI, only 84 percent of them are public benefits, the major source of income. For 13 percent of the beneficiaries, family income is the major source of financial support. For slightly less than 2 percent of the beneficiaries, earnings, interest, dividends, or rent payments are their primary sources of income. A simple comparison of primary income supports for the recipients and non-recipients of 
benefits and work incentives counseling services demonstrates that the beneficiaries who have substantial personal or family income are more likely to seek assistance from benefit advisors to improve their understanding of the social insurance system compared to the beneficiaries whose livelihoods exclusively depends on public benefits.

Although the descriptive analysis shows that beneficiaries are uniformly distributed across age groups with the exception of pre-retirees (56-65), with only 7.1 percent of all beneficiaries, there is a weak indication that the youngest segment of the beneficiary population (18-25) has a higher tendency for participation in benefits and work incentives counseling services. The descriptive statistics show that, compared to the race distribution of the general population, Whites and Hispanics are underrepresented in our sample, while African Americans are overrepresented. Specifically, about 59 percent of these beneficiaries are Non-Hispanic Whites, 27 percent are Non-Hispanic Blacks and 10 percent are Hispanics. The comparison of the race distribution between participants and non-participants demonstrate that Non-Hispanic Whites are more likely to be enrolled in the benefits counseling services compared to NonHispanic Blacks and Hispanics. For less than half of the beneficiaries in the sample, the highest educational attainment is below a high school (HS) diploma, and for about 28 percent it is a HS diploma or a certificate equivalent to it. About 20 percent of the beneficiaries attended some college courses and only 8 percent received a college diploma. Interestingly, a comparison of educational distribution for the recipients of the services and non-recipients reveals that the low educated beneficiaries are less likely to assign themselves into benefit counseling services compared to the beneficiaries with HS diploma or some college education. About 85 percent of the beneficiaries in the sample live in homes owned or rented by them or their family members. Only 9 percent of the beneficiaries live in community residential or group homes. Finally, 6 percent of the beneficiaries, at the time of application for vocational rehabilitation services, live in rehabilitation, mental health, nursing home, adult correctional facilities, halfway houses, substance abuse treatment centers, or homeless shelters. Descriptive statistics show that beneficiaries living in private residences have a higher likelihood of benefits and participation in work incentives counseling programs.

In connection with employment outcomes such as successful case closure, weekly earnings, and working hours, Table 4 shows that only 49 percent of the beneficiaries exited the Vocational Rehabilitation system with jobs in competitive settings, earning on average \$224 and 
working 24 hours per week. An unadjusted comparison of outcomes between recipients and non-recipients of the services reveals that the cases for the recipients are more likely to be successfully closed (54.3 percent vs. 48.5 percent) and on average, the recipients earn $\$ 50$ and work 3.5 hours per week more than the non-recipients.

\section{Results}

Before starting the discussion of the results received using the PSM method, first we will discuss to what extent the samples of treated and non-treated beneficiaries are balanced, with respect to variables included in vector $\boldsymbol{X}$. Then we will discuss the factors associated with nonrandom selection into services. Analysis of the extent of covariate balancing in matched samples used in this study reveals that, after matching, two samples of beneficiaries are quite comparable (See Table 5). Specifically, a t-statistic for the difference in means across the two samples for each element of $\boldsymbol{X}$ doesn't exceed 1.67, the critical value at the 10-percent level. This provides modest evidence that the balancing property of the PSM method has been possibly satisfied in our study.

To discuss the factors associated with selection into services, Table 5 reports the coefficients from the probit regression used to compute the propensity score for each beneficiary to balance the samples. Surprisingly, the presence of secondary disability increases, while age decreases the likelihood of service participation, implying that young beneficiaries with secondary disabling conditions are more likely to participate in benefits and work incentives counseling services. Male beneficiaries are less likely to receive benefits and work incentives counseling services, similar to recipients of SSI benefits. For the latter group, the probability of receipt of benefits and work incentives counseling services slightly increases with the receipt of SSDI benefits, implying that previous work experiences may facilitate a beneficiary's intent to work. Interestingly, beneficiaries with substantial family support are more likely to look for benefits and work incentives counseling services. Among disability groups, beneficiaries with sensory/visual impairments, holding all else equal, are less likely to receive the services, compared to beneficiaries with mental disorders or physical impairments. Partially, this result can be explained by the higher SGA level for individuals who are blind according to SSA's disability standard. There are some minor racial disparities in the receipt of services. Specifically, comparing to White and Black beneficiaries, Hispanic beneficiaries are less likely to seek information about benefits and work incentives counseling services if they want to 
transition into full employment; however, we could not find any disparity across White and Black beneficiaries. Beneficiaries with HS diplomas or some college education were more likely to receive benefits and work incentives counseling than beneficiaries with less education. Return on education increases with the educational attainment of beneficiaries; therefore, the problem of overpayment or termination of cash or in-kind benefits can be more legitimate among beneficiaries with more education. Finally, the last factor explaining the selection into the services is the living arrangement of the beneficiaries. Compared to the beneficiaries residing in private dwellings, the beneficiaries living in community or group homes can be less likely to receive benefits and work incentives counseling services. The latter probably is another measure of the severity of the disabling condition, in that beneficiaries in community or group homes often represent a more disabled population of beneficiaries.

Based on computed propensity scores, we match each beneficiary from the treatment group with at least two beneficiaries from the comparison group with the similar propensity scores allowing the caliper width 0.001 . The process of matching is implemented with no replacement. Then the matched beneficiaries are compared across three outcomes of interest such as the probability of successful case closure, weekly earnings, and weekly working hours.

As reported in Table 6, the unconditional difference in the probability of successful case closure between two groups is 5.8 percentage points or 11 percent. After controlling for nonrandom selection of beneficiaries into benefit counseling services, the effect of services on those who received treatment slightly increased to 6.4 percentage points. This result implies that recipients of services have a 6.4 percentage points higher probability of achieving employment in a competitive setting and the control for non-random selection into services has only marginally changed the estimate. With respect to weekly earnings, the unconditional difference between two groups is $\$ 51$ per week (19 percent), while conditional on the propensity score, the difference in earnings decreases to $\$ 34$ per week (13 percent) preserving statistical significance at the 1-percent level. Similarly, the comparative analysis using the PSM method for weekly working hours reveals that after conditioning for the propensity score, the difference in weekly working hours decreases from 3.5 hours (13 percent) to 3 hours (11 percent) between treated and non-treated groups. The comparison of the unmatched results with the results received using the PSM method indicates how it is important to control for non-random selection of the beneficiaries into benefit counseling services. Furthermore, it indicates that a control for non- 
random selection of beneficiaries into services may have a larger implication for analyses of weekly earnings and working hours, compared to the probability of successful case closure.

In Table 7, we report the estimates of the effectiveness of benefits and work incentives counseling services utilizing the IV approach. First, the results show that the effect of benefits and work incentives counseling services is comparable across the two statistical methods. Using the IV approach, we find that the benefits and work incentives counseling services increase the probability of successful case closure by 9 percent on average, which is somewhat close to 11.7 percent using the PSM method, although the former estimate is not statistically significant at any conventional level. Interestingly, the effect of benefits and work incentives counseling services on working hours and weekly earnings are much larger for the IV approach, 31 percent and 40 percent, respectively, compared to the PSM method, 13 percent and 11 percent. Regardless of the method of estimation, we find that benefits and work incentives counseling services improve the prospect of successful case closure and employment outcomes of SSI/SSDI beneficiaries.

The full results from the IV approach can be found in Appendix II. One important aspect of the IV approach is the level of association between the instrumental variable and the selection into benefits and work incentives counseling services. As indicated in equation (11), the weak correlation between the instrumental variable and receiving benefits and work incentives counseling services may lead to erroneous inferences about the relationship of interest. Therefore, it is important to show the strong significance of the parameter for the instrumental variable in the selection equation. Our results show that the percentage of beneficiaries in the district who do not receive benefit counseling services is strongly and negatively correlated with receiving services with t-statistic above 28 .

The strong correlation between the instrumental variable and the probability of being selected for benefits and work incentives counseling services in the IV method enables us to further simulate the long-run effect of an increase in the districts' capacity to provide services and future employment outcomes of the typical SSI/SSDI beneficiary. The simulation exercise reveals that a steady decrease in the percentage of beneficiaries who do not receive benefits and work incentives counseling services in the district office from 100 percent to 90 percent will have virtually no impact on the probability of successful case closure (See Figure 2), and will increase the average weekly earnings of the typical beneficiaries by $\$ 10$ per week (See Figure 3), and working hours by slightly less than 1 hour per week (See Figure 4). 


\section{Conclusion}

In this paper, we estimate the effect of benefits and work incentives counseling services on labor market outcomes of SSI/SSDI beneficiaries participating in the VR programs in the period between 2003 and 2009 in New York State. By explicitly controlling for non-random selection of beneficiaries into the services using the PSM and IV methods, the paper contributes to the literature by providing the more precise estimates of causal relationships between benefits and work incentives counseling services and labor market outcomes of beneficiaries. We find that the effect of benefits and work incentives counseling on the probability of successful case closure can be positive, which concurs with the findings of previous studies in the literature (Delin, Hartman, and Sell, 2010; Livermore and Prenovitz, 2010; and Peikes, Moreno, and Orzol, 2012). However, after accounting for non-random selection into the services using the IV method, our estimate becomes statistically insignificant. At the same time, the estimates of the effects of benefits and work incentives counseling on earnings and working hours at closure are more stable and substantial in magnitude, confirming the findings of previous studies (Tremblay et al., 2006; Delin, Hartman and Sell, 2010; and Gruman et al., 2010). Specifically, the ATET estimates for the effects on earnings and working hours are 13 percent and 11 percent, while the LATE estimates are 40 percent and 31 percent, respectively.

The main mechanism through which benefits and work incentives counseling services may impact earnings or working hours of beneficiaries is that these services eliminate any informational gap among SSA beneficiaries about the impact of employment on cash and in-kind benefits and work incentive options embedded into the existing disability benefit system (Kregel, 2009). Fear of losing benefits and lack of information about work incentives are recognized as the main barriers to employment among SSA beneficiaries (Livermore, Roche, and Prenovitz, 2009; and Kregel and O'Mara, 2011). Furthermore, any work-oriented beneficiary is faced with a quite complex tradeoff between welfare program eligibility and higher earnings in the process of employment (Delin, Hartman, and Sell, 2010). By being engaged within a confidential setting in benefits and work incentives counseling services, a typical work-oriented beneficiary can obtain complete and individualized information on the way employment and specifically, higher earnings, would impact his/her future program participation, ameliorating the tradeoff between higher earnings and maintenance of benefit eligibility (Delin, Hartman, and Sell, 2010). Additionally, after the receipt of services, the beneficiary improves his/her understanding of all 
the work incentives available for any work-oriented beneficiary of SSA disability benefits. As a result, equipped with better information, the beneficiary pursues his/her employment goals without fear of losing cash or in-kind benefits simultaneously, increasing the use of various work incentive options embedded into the system, resulting in consequent improvement in earning capacity and labor market attachment.

Kregel (2009) points out that a key principle of any employment services should be a timely reaction of the system to beneficiaries' commitments to obtain or return to employment. Unfortunately, many district offices do not have enough human resources to assist the beneficiaries to the point at which the beneficiaries have made a serious commitment to return to work. As a result, many beneficiaries with strong employment intentions stay out of the labor force without well-developed employment plans. This suggests the further need to solve the current problem of the shortage of highly trained benefits and work incentives counselors in the disability system. Our study revealed that many New York State VR district offices did not provide benefits and work incentives counseling services to any of SSI/SSDI beneficiaries in the period between 2003 and 2009. Our simulation results show that by solely increasing the provision of benefits and work incentives counseling services across all district offices in New York State from 0 to 10 percent, on average, the weekly earnings of the typical beneficiary may increase by $\$ 10$ per week. Accounting for all SSI/SSDI beneficiaries who participated in the VR programs in New York State in the study period, our rough estimates show that a 10 percentage points increase in the districts' capacity to provide benefits and work incentives counseling services will lead to an aggregate increase of earnings by $\$ 190,000$ per week or about $\$ 10$ million per year across all VR SSI/SSDI beneficiaries. Assuming the marginal tax rate of 10 percent on an additional taxable income between $\$ 0$ and $\$ 10,000$, the aggregate increase in earnings will translate into an approximately $\$ 1$ million increase in the collected tax revenues from higher earnings of beneficiaries in a single year. These additional tax revenues, without considering any potential savings received from transitioning some beneficiaries off of the SSI/SSDI rolls, will easily compensate all the expenses related with preparing about 600 certified benefits and work incentives counselors in New York State. A large inflow of benefits and work incentives counselors will drastically reduce workloads of existing counselors and undoubtedly, increase the quality of the provided services. This economic analysis demonstrates that benefits and work incentives counseling services may not only improve labor market outcomes of 
SSI/SSDI beneficiaries but also, in a single year, generate enough revenue to offset any expenses related to preparing a large number of benefits and work incentives counselors.

It is important to note several limitations of the current study. First, we use employment information only at the time of case closure, limiting our investigation to a cross-sectional setting. If we had access to the longitudinal information on beneficiaries' earnings and working hours, this could potentially enhance our further empirical investigation, enabling us to gain a better understanding of the level of persistency of positive associations between benefits and work incentives counseling services and employment outcomes. Furthermore, the longitudinal information on beneficiaries' employment outcomes could help us shed light on the speed of transitioning off the SSI/SSDI rolls after the receipt of benefits and work incentives counseling services. Second, we do not consider the possible complimentary impact of other vocational rehabilitation services on beneficiaries' employment outcomes. Benefits counseling can be considered as a supplementary service to other employment enhancing services designed to improve the vocational rehabilitation process (Gruman, et al., 2010). If the recipients of benefits and work incentives counseling services systematically receive different sets of vocational rehabilitation services compared to their counterparts, then this fact can partially explain large effects of benefits and work incentives counseling on earnings and working hours in our study. These remaining questions offer fertile areas for further exploration in the future, where such limitations can be addressed. 


\section{References}

Aakvik, A., J. Heckman, and E. Vytlacil. 2005. "Estimating Treatment Effects for Discrete Outcomes When Responses to Treatment Vary: An Application to Norwegian Vocational Rehabilitation Programs." Journal of Econometrics 125: 15-51.

Dehejia, Rajeev H. and Sadek Wahba. 2002. "Propensity Score-Matching Methods for Nonexperimental Causal Studies." The Review of Economics and Statistics 84(1): 151161.

Delin, B. S., E. A. Hartman, and C. W. Sell. 2010. "Does Work Incentive Benefits Counseling Improve Employment Outcomes for Those with Serious Disabilities? Preliminary Evidence for the "Work Oriented" from Two Demonstration Projects." Boston, MA: APPAM Research Conference.

Golden, T. P., S. O. Mara, C. Ferrell, and J. R. Sheldon. 2000. "A Theoretical Construct for Benefits Planning and Assistance in the Ticket to Work and Work Incentive Improvement Act.” Journal of Vocational Rehabilitation 14: 147-152.

Gruman, C., N. Shugrue, K. Kellett, J. Robison, and A. Porter. 2010. "Medicaid Infrastructure Grant: The Impact of Benefits Counseling and Vocational Rehabilitation on Earnings." Working Paper. Farmington, CT: University of Connecticut Health Center.

Hennessey, J. and S. Muller. 1995. "The Effect of Vocational Rehabilitation and Work Incentives on Helping the Disabled-Worker Beneficiary Back to Work." Social Security Bulletin 58(1): 15-28.

Kregel, J. 2009. "Work Incentives Planning and Assistance: Assisting Beneficiaries to Obtain Employment and Reduce Dependence on SSA Benefits." Journal of Vocational Rehabilitation 31: 1-9.

Kregel, J., and S. O. Mara. 2011. "Work Incentive Counseling as a Workplace Support." Journal of Vocational Rehabilitation 35: 73-83.

Livermore G., A. Roche, and S. Prenovitz. 2009. "Work Activity and Use of Employment Supports Under the Original Ticket to Work Regulations SSI and DI Beneficiaries with Work-Related Goals and Expectations." Final Report. Washington, DC: Mathematica Policy Research.

Livermore G., and S. Prenovitz. 2010. "Work Activity and Use of Employment Supports Under the Original Ticket to Work Regulations Benefits Planning, Assistance, and Outreach (BPAO) Service User Characteristics and Use of Work Incentives.” Final Report. Washington, DC: Mathematica Policy Research. 
Livermore, G., S. Prenovitz, and J. Schimmel. 2011. "Employment-Related Outcomes of a Recent Cohort of Work Incentives Planning and Assistance (WIPA) Program Enrollees." Final Report. Washington, DC: Mathematica Policy Research.

Peikes, D. N., L. Moreno, and S. M. Orzol. 2012. "Propensity Score Matching." The American Statistician 62(3): 222-231.

Thornton, C., T. Fraker, G. Livermore, D. Stapleton, B. O’Day, D. Wittenburg, R. Weathers, N. Goodman, T. Silva, E. Martin Sama, J. Gregory, D. Wright, and A. Mamun. 2007. "Evaluation of the Ticket to Work Program: Assessment of Post-Rollout Implementation and Early Impacts.” Washington, DC: Mathematica Policy Research.

Tremblay, T., J. Smith, H. Xie, and R. Drake. 2004. “The Impact of Specialized Benefits Counseling Services on Social Security Administration Disability Beneficiaries in Vermont." Journal of Rehabilitation 70(2): 5-11.

Tremblay, T., J. Smith, H. Xie, and R. Drake. 2006. "Effect of Benefits Counseling Services on Employment Outcomes for People with Psychiatric Disabilities." Psychiatric Services 57(6): 816-821. 
Table 1. Literature on Effectiveness of Benefit Counseling

\begin{tabular}{|c|c|c|c|c|}
\hline Authors & Sample size & SSA region & Methods & Outcomes \\
\hline Tremblay, et al. (2004) & 2,016 & Vermont & $\begin{array}{l}\text { Mixed effect multivariate } \\
\text { linear regression }\end{array}$ & Earnings \\
\hline Tremblay, et al. (2006) & 1,092 & $\begin{array}{c}\text { Vermont, } \\
\text { beneficiaries with } \\
\text { psychiatric disabilities }\end{array}$ & $\begin{array}{l}\text { Mixed effect multivariate } \\
\text { linear regression }\end{array}$ & Earnings \\
\hline $\begin{array}{l}\text { Delin, Hartman, and Sell } \\
\text { (2010) }\end{array}$ & 911 & Wisconsin & $\begin{array}{c}\text { Mixed effect multivariate } \\
\text { linear regression, } \\
\text { MANOVA }\end{array}$ & $\begin{array}{l}\text { Earnings. } \\
\text { Employment } \\
\text { and Income }\end{array}$ \\
\hline Gruman, et al. (2010) & 5,675 & Connecticut & $\begin{array}{l}\text { Non-parametric comparison } \\
\text { of means before and after, } \\
\text { Multivariate logistic } \\
\text { regressions }\end{array}$ & Employment \\
\hline $\begin{array}{l}\text { Livermore and Prenovitz } \\
\text { (2010) }\end{array}$ & 118,357 & Nationwide & $\begin{array}{c}\text { Non-parametric comparison } \\
\text { of means }\end{array}$ & $\begin{array}{c}\text { Employment, } \\
\text { Earnings, } \\
\text { Work } \\
\text { Incentives, } \\
\text { SSI/SSDI } \\
\text { Benefits } \\
\text { Termination }\end{array}$ \\
\hline $\begin{array}{l}\text { Livermore, Prenovitz, and } \\
\text { Schimmel (2011) }\end{array}$ & 12,610 & Nationwide & $\begin{array}{l}\text { Multivariate logistic } \\
\text { regressions }\end{array}$ & $\begin{array}{l}\text { Services, Work } \\
\text { Incentives, } \\
\text { Employment, } \\
\text { Earnings, } \\
\text { Benefit } \\
\text { Reduction, } \\
\text { SSI/SSDI } \\
\text { Benefits } \\
\text { Termination }\end{array}$ \\
\hline $\begin{array}{l}\text { Peikes, Moreno, and Orzol } \\
\text { (2012) }\end{array}$ & 3,596 & $\begin{array}{c}\text { New York, New } \\
\text { Hampshire, } \\
\text { Oklahoma }\end{array}$ & $\begin{array}{c}\text { Randomized Control Trials } \\
\text { and Propensity Score } \\
\text { Matching }\end{array}$ & $\begin{array}{l}\text { Earnings and } \\
\text { Employment }\end{array}$ \\
\hline
\end{tabular}


Table 2. Benefit Counseling and Its Association with Employment and Earnings

\begin{tabular}{|c|c|c|}
\hline Authors & Employment & Earnings \\
\hline Tremblay, et al. (2004) & - & $\begin{array}{l}\text { Earnings gap between } \\
\text { recipients of BC services and } \\
\text { other non-recipients is } \\
\text { between } \$ 190-\$ 225 \text { per } \\
\text { person per quarter }\end{array}$ \\
\hline Tremblay, et al. (2006) & - & $\begin{array}{c}\text { Earnings gap between } \\
\text { recipients of BC services and } \\
\text { other non-recipients is } \$ 318 \\
\text { per person- quarter }\end{array}$ \\
\hline $\begin{array}{l}\text { Delin, Hartman, and Sell } \\
\text { (2010) }\end{array}$ & $\begin{array}{l}\text { Relative to the lowest dosage } \\
\text { group, the medium dosage } \\
\text { group's employment rate } \\
\text { increased by } 1.1 \% \text { and the } \\
\text { high dosage group's } \\
\text { employment rate increased by } \\
2.2 \%\end{array}$ & $\begin{array}{l}\text { Relative to the lowest dosage } \\
\text { group, the medium dosage } \\
\text { group's mean earnings } \\
\text { increased by } \$ 34.30 \text { and the } \\
\text { high dosage group's mean } \\
\text { earnings increased by } \$ 68.3 \\
\text { per quarter (the difference is } \\
\text { higher for previously } \\
\text { employed recipients) }\end{array}$ \\
\hline Gruman, et al. (2010) & $\begin{array}{l}\text { The study estimates the } \\
\text { factors associated with } \\
\text { employment, so the } \\
\text { association between BC and } \\
\text { employment is unidentified }\end{array}$ & $\begin{array}{l}\text { BC recipients' earnings } \\
\text { increased by } \$ 200 \text { and BC/VR } \\
\text { recipients' earnings increased } \\
\text { by } \$ 400 \text { in the first quarter of } \\
\text { intervention (after the first } \\
\text { month of intervention, the } \\
\text { earnings started declining for } \\
\text { both groups) }\end{array}$ \\
\hline $\begin{array}{l}\text { Livermore and Prenovitz } \\
(2010)\end{array}$ & $\begin{array}{l}39 \% \text { of } \mathrm{BC} \text { recipients were } \\
\text { not employed compared to } \\
73 \% \text { among all beneficiaries }\end{array}$ & $\begin{array}{l}\text { Mean of annual earnings is } \\
\$ 6,778 \text { among BC recipients } \\
\text { compared to } \$ 6,442 \text { among all } \\
\text { beneficiaries }\end{array}$ \\
\hline $\begin{array}{l}\text { Livermore, Prenovitz, and } \\
\text { Schimmel (2011) }\end{array}$ & $\begin{array}{l}\text { Relative to those who } \\
\text { received less than } 3 \text { hours of } \\
\text { BC, } 3-6 \text { hours BC recipients } \\
\text { have a } 11 \% \text { and above } 6 \\
\text { hours } \mathrm{BC} \text { recipients a } 39 \% \\
\text { higher chance of employment }\end{array}$ & $\begin{array}{c}\text { Relative to those who received } \\
\text { less than } 3 \text { hours of BC, 3-6 } \\
\text { hours BC recipients have a } \\
31 \% \text { and above } 6 \text { hours BC } \\
\text { recipients a } 60 \% \text { higher } \\
\text { chance of an increase in } \\
\text { earnings }\end{array}$ \\
\hline $\begin{array}{l}\text { Peikes, Moreno, and Orzol } \\
\text { (2012) (only for recipients of } \\
\text { benefit counseling services in } \\
\text { New York State) }\end{array}$ & $\begin{array}{l}\text { A 9-14\% point higher } \\
\text { employment rate for BC } \\
\text { recipients relative to non- } \\
\text { recipients }\end{array}$ & $\begin{array}{c}\text { For PSM, a } \$ 1,214 \text { higher } \\
\text { change in earnings and for } \\
\text { RTC, a } \$ 1,080 \text { lower change } \\
\text { in earnings in the year of BC } \\
\text { receipt relative to the year } \\
\text { before }\end{array}$ \\
\hline
\end{tabular}


Table 3. Definitions of Key Variables Used in the Study

\begin{tabular}{|c|c|c|}
\hline Variable & Definition & Type \\
\hline \multicolumn{3}{|c|}{ Dependent Variables } \\
\hline $\begin{array}{l}\text { Successful case } \\
\text { closure }\end{array}$ & $\begin{array}{l}\text { Whether the service record was closed with an employment } \\
\text { outcome ( } 90 \text { days of consecutive employment) }\end{array}$ & Dummy \\
\hline Weekly earnings & $\begin{array}{l}\text { Weekly earnings at closure include all income from wages, salaries, } \\
\text { tips, and commissions before payroll deductions of Federal, State, } \\
\text { and local income taxes and Social Security payroll tax. }\end{array}$ & Continuous \\
\hline Working hours & $\begin{array}{l}\text { The number of hours the individual worked for earnings in a typical } \\
\text { week when the service record was closed }\end{array}$ & Continuous \\
\hline \multicolumn{3}{|c|}{ Instrumental Variable } \\
\hline $\begin{array}{l}\text { District-level } \\
\text { instrument }\end{array}$ & $\begin{array}{l}\text { The percentage of beneficiaries in the district who do not receive } \\
\text { benefit counseling }\end{array}$ & Continuous \\
\hline \multicolumn{3}{|c|}{ Control Variables } \\
\hline Married & Whether the individual was married at application & Dummy \\
\hline Male & Whether gender of the individual is male & Dummy \\
\hline Veteran status & $\begin{array}{l}\text { Whether the individual had served in the active military, naval, or } \\
\text { air service, and was discharged or released under conditions other } \\
\text { than dishonorable }\end{array}$ & Dummy \\
\hline $\begin{array}{l}\text { Unemployment } \\
\text { rate }\end{array}$ & County unemployment rate on the day of case closure & Continuous \\
\hline $\begin{array}{l}\text { Supplemental } \\
\text { Security Income }\end{array}$ & $\begin{array}{l}\text { Whether the individual was receiving Supplement Security Income } \\
\text { benefits at application }\end{array}$ & Dummy \\
\hline SSI and SSDI & $\begin{array}{l}\text { Whether the individual was receiving Supplement Security Income } \\
\text { and Social Security Disability Income benefits at application }\end{array}$ & Dummy \\
\hline $\begin{array}{l}\text { Primary } \\
\text { disability }\end{array}$ & $\begin{array}{l}\text { The primary physical or mental impairment that causes or results in } \\
\text { a substantial impediment to employment: } 1 \text { - } \\
\text { Sensory/Communicative; } 2 \text { - Physical; } 3 \text { - Mental }\end{array}$ & Categorical \\
\hline $\begin{array}{l}\text { Secondary } \\
\text { disability }\end{array}$ & $\begin{array}{l}\text { Whether the individual has the physical or mental impairment that } \\
\text { contributes to the impediment to employment not in the primary } \\
\text { basis }\end{array}$ & Dummy \\
\hline Age & Years since data of birth at application & Continuous \\
\hline Race & $\begin{array}{l}\text { Self or observer-identified race and ethnicity: } 1 \text { - Non-Hispanic } \\
\text { White; } 2 \text { - Non-Hispanic Black; } 3 \text { - Hispanic; } 4 \text { - Asian; } 5 \text { - Other }\end{array}$ & Categorical \\
\hline Education & $\begin{array}{l}\text { Highest educational attainment at closure: } 1 \text { - Below High School; } \\
\text { 2-HS Diploma; } 3 \text { - Some College; } 4 \text { - College + } \\
\text { Living Arrangement of the individual at application: } 1 \text { - Private }\end{array}$ & Categorical \\
\hline $\begin{array}{l}\text { Living } \\
\text { arrangement }\end{array}$ & $\begin{array}{l}\text { Residence; } 2 \text { - Community Residential / Group Home; } 3 \text { - } \\
\text { \{Rehabilitation Facility, Mental Health Facility, Nursing Home, } \\
\text { Adult Correctional Facility, Halfway House, Substance Abuse } \\
\text { Treatment Center, Homeless/Shelter }\}\end{array}$ & Categorical \\
\hline $\begin{array}{l}\text { Primary source of } \\
\text { support }\end{array}$ & $\begin{array}{l}\text { The individual's largest single source of support at application: } 1 \text { - } \\
\text { Personal Income; } 2 \text { - Family and Friends; } 3 \text {-Public Support. }\end{array}$ & Categorical \\
\hline
\end{tabular}


Table 4. Descriptive Statistics on Key Variables

\begin{tabular}{|c|c|c|c|c|}
\hline Variables & All & Recipients & Non-recipients & Difference \\
\hline Married & $12.5 \%$ & $16.1 \%$ & $12.4 \%$ & $\operatorname{Pr}<0.01$ \\
\hline Male & $56.1 \%$ & $51.0 \%$ & $56.2 \%$ & $\operatorname{Pr}<0.01$ \\
\hline Veteran status & $3.1 \%$ & $3.1 \%$ & $3.1 \%$ & $\operatorname{Pr}=0.942$ \\
\hline County unemployment rate & 6.1 & 6.6 & 6.1 & $\operatorname{Pr}<0.01$ \\
\hline Supplemental Security Income & $60.2 \%$ & $15.6 \%$ & $60.9 \%$ & $\operatorname{Pr}<0.01$ \\
\hline SSI and SSDI & $13.6 \%$ & $4.0 \%$ & $13.8 \%$ & $\operatorname{Pr}<0.01$ \\
\hline Secondary disability & $59.0 \%$ & $70.3 \%$ & $58.8 \%$ & $\operatorname{Pr}<0.01$ \\
\hline \multicolumn{5}{|l|}{ Primary disability type: } \\
\hline Sensory & $5.3 \%$ & $3.2 \%$ & $5.3 \%$ & \multirow{3}{*}{$\operatorname{Pr}<0.01$} \\
\hline Physical & $22.4 \%$ & $29.3 \%$ & $22.3 \%$ & \\
\hline Mental & $72.3 \%$ & $67.5 \%$ & $72.3 \%$ & \\
\hline \multicolumn{5}{|l|}{ Age Group } \\
\hline $18-25$ & $24.2 \%$ & $27.0 \%$ & $24.2 \%$ & \multirow{5}{*}{$\operatorname{Pr}=0.046$} \\
\hline $25-35$ & $20.5 \%$ & $16.1 \%$ & $20.6 \%$ & \\
\hline $36-45$ & $26.6 \%$ & $25.9 \%$ & $26.6 \%$ & \\
\hline $46-55$ & $21.7 \%$ & $23.5 \%$ & $21.6 \%$ & \\
\hline $56-65$ & $7.1 \%$ & $7.6 \%$ & $7.1 \%$ & \\
\hline \multicolumn{5}{|l|}{ Race Group } \\
\hline White & $58.5 \%$ & $67.4 \%$ & $58.4 \%$ & \multirow{5}{*}{$\operatorname{Pr}<0.01$} \\
\hline Black & $26.5 \%$ & $22.2 \%$ & $26.6 \%$ & \\
\hline Hispanic & $10.3 \%$ & $4.5 \%$ & $10.4 \%$ & \\
\hline Asian & $1.5 \%$ & $0.8 \%$ & $1.5 \%$ & \\
\hline Other & $3.2 \%$ & $5.1 \%$ & $3.2 \%$ & \\
\hline \multicolumn{5}{|l|}{ Education } \\
\hline No high school (HS) diploma & $44.4 \%$ & $33.9 \%$ & $44.5 \%$ & \multirow{4}{*}{$\operatorname{Pr}<0.01$} \\
\hline HS Diploma & $27.8 \%$ & $31.5 \%$ & $27.7 \%$ & \\
\hline Some college & $19.5 \%$ & $25.9 \%$ & $19.4 \%$ & \\
\hline College + & $8.4 \%$ & $8.7 \%$ & $8.4 \%$ & \\
\hline \multicolumn{5}{|l|}{ Living arrangements } \\
\hline Private & $84.7 \%$ & $93.6 \%$ & $84.5 \%$ & \multirow{3}{*}{$\operatorname{Pr}<0.01$} \\
\hline Community & $9.0 \%$ & $1.8 \%$ & $9.2 \%$ & \\
\hline Residential & $6.3 \%$ & $4.7 \%$ & $6.3 \%$ & \\
\hline \multicolumn{5}{|l|}{ Income source } \\
\hline Personal & $1.9 \%$ & $8.4 \%$ & $1.8 \%$ & \multirow{3}{*}{$\operatorname{Pr}<0.01$} \\
\hline Family & $12.9 \%$ & $34.1 \%$ & $12.6 \%$ & \\
\hline Public & $84.1 \%$ & $57.2 \%$ & $84.5 \%$ & \\
\hline \multicolumn{5}{|l|}{ Employment outcomes } \\
\hline Successful case closure & $48.6 \%$ & $54.3 \%$ & $48.5 \%$ & $\operatorname{Pr}<0.01$ \\
\hline Wages & 224.3(167.6) & 274.3(181.3) & 223.4(167.2) & $\operatorname{Pr}<0.01$ \\
\hline Working hours & $24.0(9.9)$ & $27.5(10.3)$ & $23.9(9.8)$ & $\operatorname{Pr}<0.01$ \\
\hline
\end{tabular}


Table 5. Factors Associated with the Receipt of Benefit Counseling

\begin{tabular}{|c|c|c|c|c|c|c|}
\hline \multirow[b]{2}{*}{ Variables } & \multicolumn{2}{|c|}{ Probit } & \multicolumn{4}{|c|}{ Balancing statistics } \\
\hline & Coefficient & SE & Treatment & Control & \%bias & t-stat. \\
\hline Secondary Disability & $0.234 * * *$ & 0.038 & 0.702 & 0.724 & -4.8 & -0.88 \\
\hline Married & -0.054 & 0.051 & 0.161 & 0.151 & 3.0 & 0.51 \\
\hline Age & $-0.017^{*}$ & 0.010 & 37.1 & 36.1 & 7.9 & 1.36 \\
\hline $\mathrm{Age}^{\wedge} 2$ & 0.000 & 0.000 & 1543.8 & 1467.2 & 8.0 & 1.40 \\
\hline Male & $-0.084^{* *}$ & 0.036 & 0.511 & 0.491 & 4.0 & 0.71 \\
\hline Veteran & -0.132 & 0.100 & 0.031 & 0.021 & 5.6 & 1.07 \\
\hline County Unemployment Rate & $0.052 * * *$ & 0.009 & 6.564 & 6.552 & 0.7 & 0.12 \\
\hline Supplemental Security Income & $-0.894 * * *$ & 0.050 & 0.156 & 0.182 & -6.0 & -1.21 \\
\hline SSI and SSDI & $0.164^{* *}$ & 0.083 & 0.040 & 0.041 & -0.3 & -0.07 \\
\hline Family Income Main Support & $0.502^{* * *}$ & 0.046 & 0.339 & 0.364 & -6.1 & -0.92 \\
\hline \multicolumn{7}{|c|}{ Primary Disability Type (Physical=reference group) } \\
\hline Sensory & $-0.235^{* *}$ & 0.096 & 0.032 & 0.037 & -2.4 & -0.47 \\
\hline Mental & -0.010 & 0.042 & 0.674 & 0.668 & 1.4 & 0.24 \\
\hline \multicolumn{7}{|c|}{ Race Group (Non-Hispanic White=reference group) } \\
\hline Non-Hispanic Black & 0.019 & 0.043 & 0.223 & 0.238 & -3.6 & -0.64 \\
\hline Hispanic & $-0.238^{* * *}$ & 0.077 & 0.045 & 0.050 & -1.9 & -0.40 \\
\hline Asian & -0.163 & 0.179 & 0.008 & 0.006 & 1.5 & 0.33 \\
\hline Other & $0.222^{* * *}$ & 0.084 & 0.048 & 0.045 & 1.6 & 0.27 \\
\hline \multicolumn{7}{|c|}{ Education (Below High School=reference group) } \\
\hline HS diploma & $0.125^{* * *}$ & 0.048 & 0.315 & 0.309 & 1.2 & 0.21 \\
\hline Some College & $0.133^{* *}$ & 0.052 & 0.260 & 0.248 & 2.7 & 0.46 \\
\hline College+ & -0.019 & 0.070 & 0.087 & 0.080 & 2.6 & 0.46 \\
\hline \multicolumn{7}{|c|}{ Living Arrangements (Private $=$ reference group) } \\
\hline Community & $-0.370^{* * *}$ & 0.111 & 0.018 & 0.019 & -0.4 & -0.11 \\
\hline Residential & -0.073 & 0.082 & 0.047 & 0.048 & -0.4 & -0.07 \\
\hline Constant & $-1.912^{* * *}$ & 0.196 & & & & \\
\hline
\end{tabular}

Table 6. Propensity Score Matching Results

\begin{tabular}{llcccccc}
\hline Variable & Sample & Treated & Controls & Difference & SE & t-stat. & \% change \\
\hline \multirow{2}{*}{ Successful case closure } & Unmatched & 0.543 & 0.485 & $0.058^{* * *}$ & 0.020 & 2.9 & $10.7 \%$ \\
\multirow{3}{*}{ Weekly earnings } & ATT & 0.544 & 0.480 & $0.064^{* *}$ & 0.026 & 2.5 & $11.7 \%$ \\
\multirow{3}{*}{ Working hours } & Unmatched & 274.3 & 223.4 & $50.9^{* * *}$ & 9.2 & 5.5 & $18.6 \%$ \\
& ATT & 274.1 & 239.8 & $34.3^{* * *}$ & 12.4 & 2.8 & $12.5 \%$ \\
& Unmatched & 27.5 & 23.9 & $3.5^{* * *}$ & 0.5 & 6.6 & $12.9 \%$ \\
& ATT & 27.4 & 24.4 & $3.0^{* * *}$ & 0.7 & 4.3 & $10.9 \%$ \\
\hline
\end{tabular}

*** significant at $1 \%$ level, ** significant at the 5\% level, * significant at the $10 \%$ level. 
Table 7. The Effect of Benefit Counseling on Outcomes

\begin{tabular}{lccccccc}
\hline Variable & Coeff. & SE & z-stat. & p-value & -95CL & -95CL & \% change \\
\hline Successful case closure (LATE) & 0.049 & 0.060 & 0.82 & 0.41 & -0.068 & 0.166 & $9.02 \%$ \\
Log of weekly earnings (LATE) & 0.395 & 0.090 & 4.41 & 0.00 & 0.219 & 0.570 & $39.5 \%$ \\
Log of working hours (LATE) & 0.310 & 0.049 & 6.32 & 0.00 & 0.214 & 0.406 & $31.0 \%$ \\
\hline
\end{tabular}

*** significant at $1 \%$ level, ** significant at the 5\% level, * significant at the $10 \%$ level.

${ }^{a}$ the marginal effect computed at the mean values of each element of the factors included in the probit regression of successful case closure in the multi-equation system. 
Figure 1. Receipt of Benefits Counseling Services by District Office

\section{$\%$ of VR SSI/SSDlers with benefit counseling}

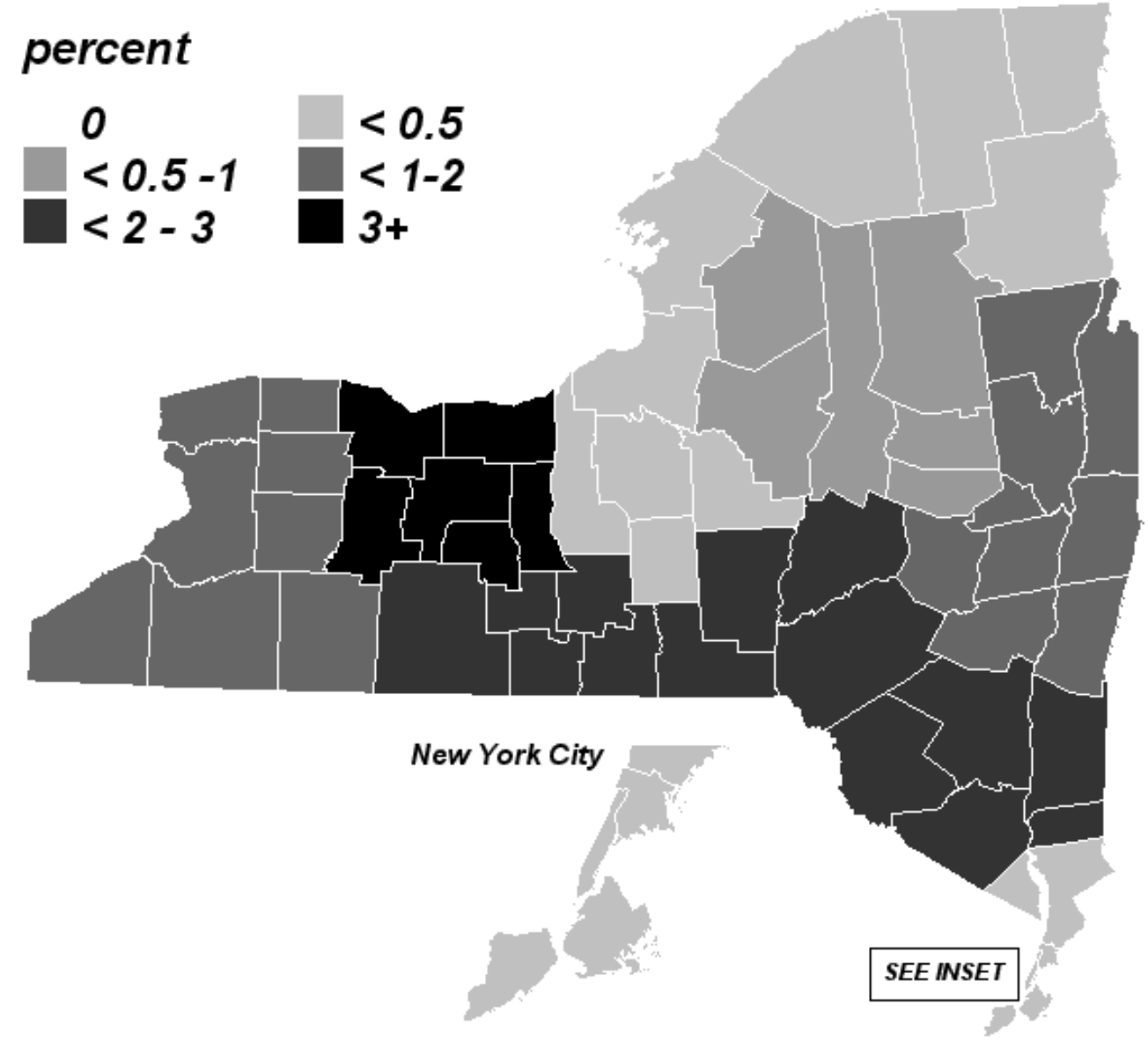


Figure 2.

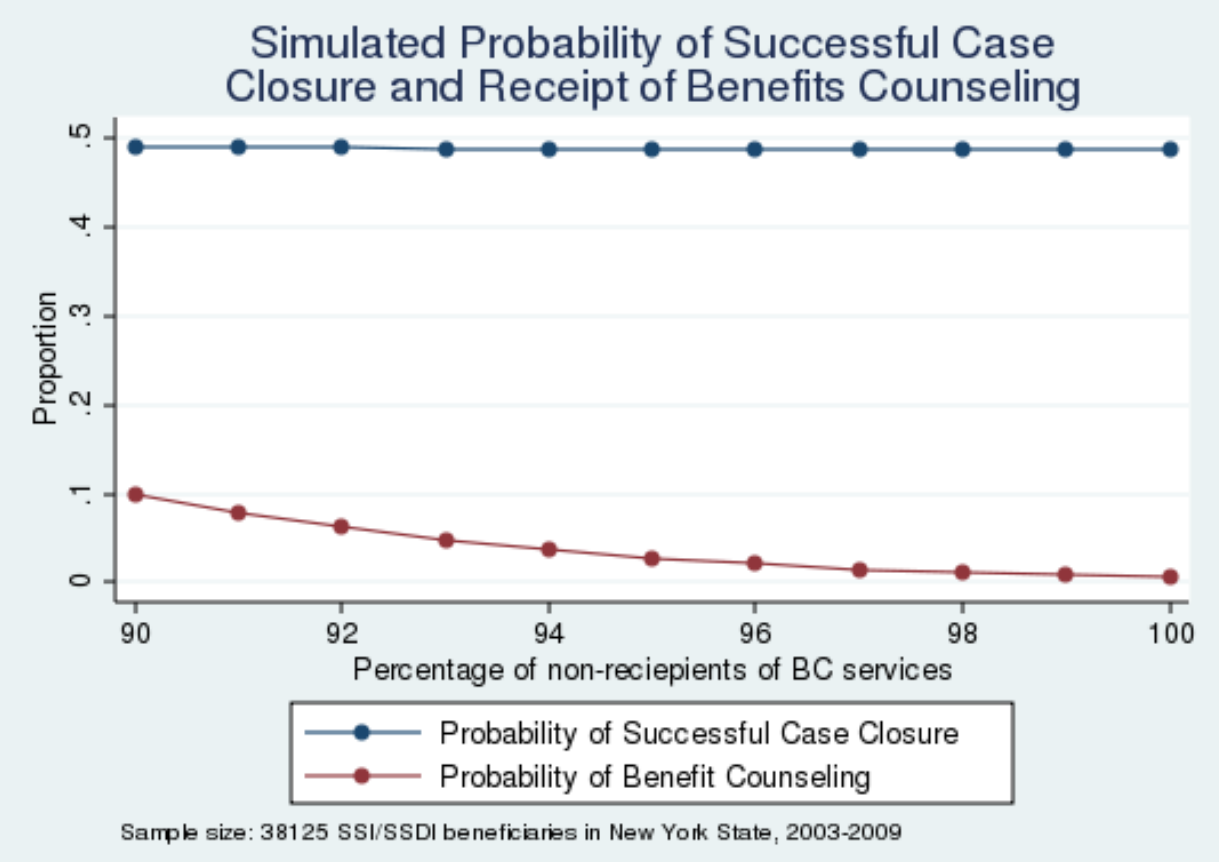

Figure 3.

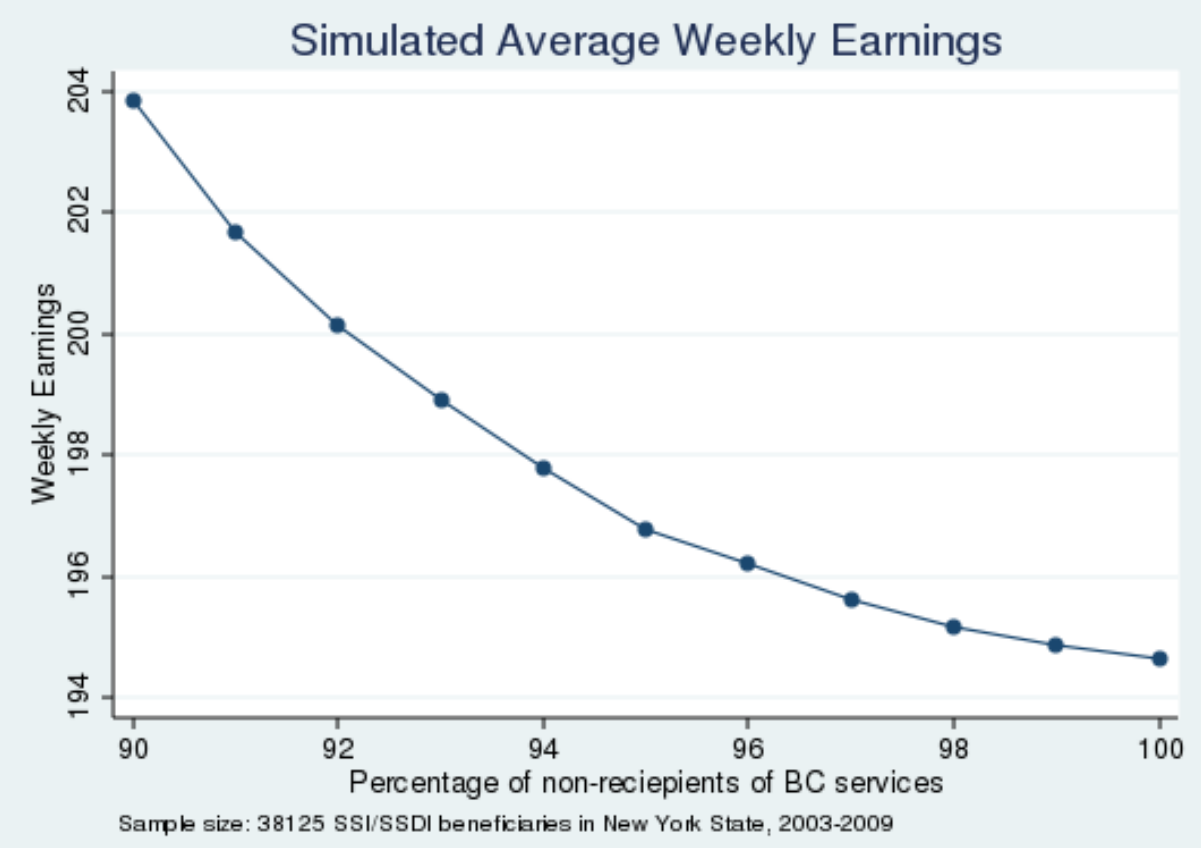


Figure 4.

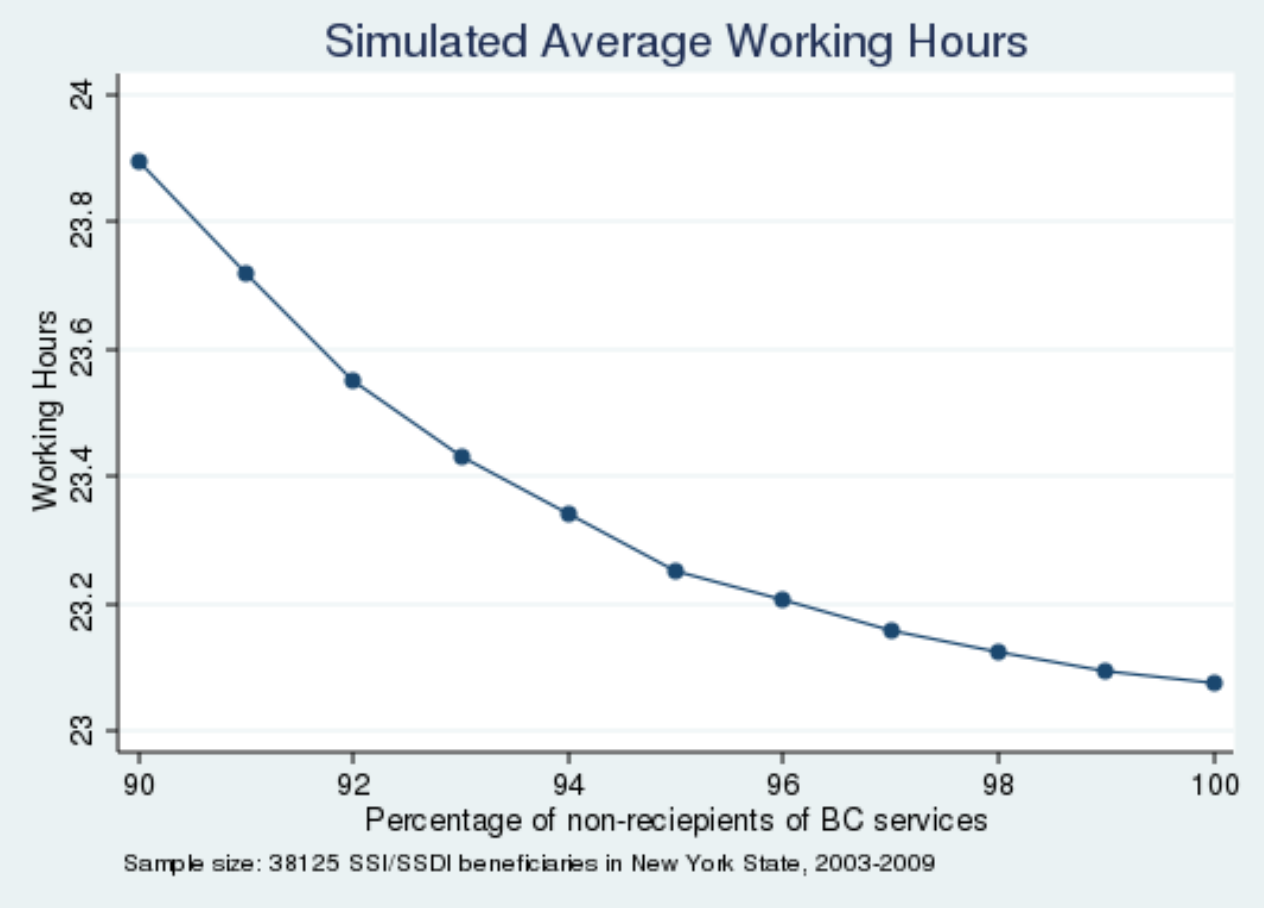




\section{Appendix 1. Empirical Model (IV approach)}

The outcome equation for weekly working hours or earnings can be described as

$$
Y_{i}^{*}=X_{i} \alpha_{1}+\Delta_{1} B_{i}+\varepsilon_{1 i}
$$

However, only the employment outcomes for the successfully rehabilitated beneficiaries are observed in the administrative data

$$
\left\{\begin{array}{l}
Y=Y_{i}^{*}, R_{i}=1 \quad \text { if } R_{i}^{*}>0 \\
Y_{i} \text { not observed, } R_{i}=0 \text { if } R_{i}^{*} \leq 0
\end{array} .\right.
$$

where $R$ is the indicator of successful case closure and $R_{i}^{*}$ is the propensity of successful rehabilitation and the latter can be given by the following linear specification

$$
\begin{gathered}
R_{i}^{*}=X_{i} \alpha_{2}++\Delta_{2} B_{i}+Q_{i} \omega_{2}+\varepsilon_{2 i}, \\
R_{i}= \begin{cases}1 \quad \text { if } \quad R_{i}^{*}>0 \\
0 & \text { if } R_{i}^{*} \leq 0\end{cases}
\end{gathered}
$$

As in the bivariate sample selection models, the selection equation given by the specification of the propensity of successful rehabilitation should contain a set of variables, $Q$, known as theoretical exclusion restrictions, which have direct impacts on the rehabilitation process and no impact on the employment outcome. For this purpose, we use such variables as the beneficiary's living arrangement and the indicator whether the family income is the main income support. Finally, the process of selection into benefit counseling services can be described by the following condition representing the propensity of the benefit counseling services receipt

$$
B_{i}^{*}=X_{i} \alpha_{3}+Q_{i} \omega_{3}+Z_{i} \gamma_{3}+\varepsilon_{3 i}
$$




$$
B_{i}= \begin{cases}1 & \text { if } B_{i}^{*}>0 \\ 0 & \text { if } B_{i}^{*} \leq 0\end{cases}
$$

The main requirement of the instrumental variable approach is to introduce a variable that has a direct impact on the selection process. In the above specification of the propensity of the benefit counseling services receipt, $Z$ represents an instrumental variable -- the percentage of beneficiaries in the district who do not receive benefit counseling -- which is assumed to be strongly correlated with the selection into benefit counseling services and affect employment outcomes of beneficiaries indirectly, only through its impact on the receipt of benefit counseling services.

In the above multi-equation system, it can be assumed that the vector of the errors $\left(\varepsilon_{1 i}, \varepsilon_{2 i}, \varepsilon_{3 i}\right)$ has the multivariate normal distribution.

$$
\begin{aligned}
& \varepsilon=\left(\varepsilon_{1 i}, \varepsilon_{2 i}, \varepsilon_{3 i}\right) \sim \mathrm{N}(0, \Sigma) \\
& \Sigma=\left|\begin{array}{ccc}
\sigma_{1}^{2} & \rho_{12} & \rho_{13} \\
\rho_{12} & 1 & \rho_{23} \\
\rho_{13} & \rho_{23} & 1
\end{array}\right|
\end{aligned}
$$

The given multi-equation system can be estimated with maximum likelihood using Geweke, Hajivassiliou and Keane (GHK) algorithm. Specifically, to estimate this multi-equation system, we use "cmp" the user-written command in STATA with 200 Halton draws for each observation in the GHK simulation of the higher-dimensional cumulative multivariate normal distribution. 


\section{Appendix 2. Full Results from the IV Approach}

Table A2.1. Results from Joint Estimation of Successful Case Closure and Benefit Counseling Equations

\begin{tabular}{|c|c|c|c|c|}
\hline \multirow[b]{2}{*}{ Variables } & \multicolumn{2}{|c|}{ Successful case closure } & \multicolumn{2}{|c|}{ Benefit counseling } \\
\hline & Coeff. & $\mathrm{SE}$ & Coeff. & SE \\
\hline Benefit counseling & 0.123 & 0.150 & - & - \\
\hline \multicolumn{5}{|l|}{ Disability type: } \\
\hline Sensory & 0.337 & 0.032 & -0.340 & 0.105 \\
\hline Mental & 0.057 & 0.017 & 0.018 & 0.046 \\
\hline Secondary disability & -0.112 & 0.013 & 0.147 & 0.041 \\
\hline Married & 0.105 & 0.021 & -0.064 & 0.055 \\
\hline Age & 0.010 & 0.004 & -0.013 & 0.011 \\
\hline $\operatorname{Age}^{\wedge} 2(* 100)$ & -0.016 & 0.005 & 0.007 & 0.014 \\
\hline \multicolumn{5}{|l|}{ Race group: } \\
\hline Black & -0.086 & 0.016 & -0.009 & 0.048 \\
\hline Hispanic & -0.064 & 0.022 & -0.064 & 0.082 \\
\hline Asian & -0.117 & 0.054 & -0.001 & 0.195 \\
\hline Other & -0.072 & 0.037 & 0.275 & 0.092 \\
\hline Male & 0.059 & 0.013 & -0.069 & 0.039 \\
\hline \multicolumn{5}{|l|}{ Education: } \\
\hline HS diploma & -0.074 & 0.017 & 0.136 & 0.053 \\
\hline Some college & -0.101 & 0.019 & 0.158 & 0.057 \\
\hline College+ & 0.064 & 0.026 & 0.043 & 0.077 \\
\hline Veteran & -0.069 & 0.038 & -0.203 & 0.112 \\
\hline Supplemental Security Income & -0.162 & 0.017 & -0.828 & 0.055 \\
\hline SSI and SSDI & -0.003 & 0.021 & 0.132 & 0.088 \\
\hline \multicolumn{5}{|l|}{ Living arrangements: } \\
\hline Community & 0.088 & 0.023 & -0.345 & 0.118 \\
\hline Residential & -0.095 & 0.027 & -0.019 & 0.091 \\
\hline Family income main support & 0.027 & 0.021 & 0.483 & 0.050 \\
\hline County unemployment rate & -0.067 & 0.003 & 0.085 & 0.010 \\
\hline District-level instrument & - & - & -0.140 & 0.005 \\
\hline Constant & 0.362 & 0.072 & 11.380 & 0.507 \\
\hline$\rho_{12}$ & 0.005 & 0.070 & & \\
\hline $\mathrm{N}$ & 38,195 & & & \\
\hline$\Lambda$ & $-28,301$ & & & \\
\hline
\end{tabular}


Table A2.2. Results from Joint Estimation of Successful Case Closure, Benefit Counseling and Working Hours Equations

\begin{tabular}{|c|c|c|c|c|c|c|}
\hline \multirow[b]{2}{*}{ Variables } & \multicolumn{2}{|c|}{ Successful case closure } & \multicolumn{2}{|c|}{ Benefit counseling } & \multicolumn{2}{|c|}{ Working hours } \\
\hline & Coeff. & SE & Coeff. & SE & Coeff. & $\mathrm{SE}$ \\
\hline Benefit counseling & 0.143 & 0.150 & - & - & 0.310 & 0.049 \\
\hline \multicolumn{7}{|l|}{ Disability type: } \\
\hline Sensory & 0.337 & 0.032 & -0.333 & 0.104 & 0.063 & 0.016 \\
\hline Mental & 0.055 & 0.017 & 0.026 & 0.046 & -0.113 & 0.009 \\
\hline Secondary disability & -0.112 & 0.013 & 0.143 & 0.041 & -0.025 & 0.007 \\
\hline Married & 0.106 & 0.021 & -0.073 & 0.055 & 0.059 & 0.011 \\
\hline Age & 0.010 & 0.004 & -0.012 & 0.011 & -0.003 & 0.002 \\
\hline $\operatorname{Age}^{\wedge} 2(* 100)$ & -0.016 & 0.005 & 0.007 & 0.014 & -0.003 & 0.002 \\
\hline \multicolumn{7}{|l|}{ Race group: } \\
\hline Black & -0.086 & 0.016 & -0.019 & 0.049 & 0.131 & 0.009 \\
\hline Hispanic & -0.064 & 0.022 & -0.065 & 0.082 & 0.171 & 0.012 \\
\hline Asian & -0.118 & 0.054 & -0.006 & 0.196 & 0.064 & 0.029 \\
\hline Other & -0.073 & 0.037 & 0.272 & 0.092 & 0.018 & 0.020 \\
\hline Male & 0.058 & 0.013 & -0.065 & 0.039 & 0.065 & 0.007 \\
\hline \multicolumn{7}{|l|}{ Education: } \\
\hline HS diploma & -0.073 & 0.017 & 0.133 & 0.052 & 0.112 & 0.009 \\
\hline Some college & -0.100 & 0.019 & 0.146 & 0.058 & 0.154 & 0.010 \\
\hline College+ & 0.066 & 0.026 & 0.024 & 0.077 & 0.164 & 0.013 \\
\hline Veteran & -0.069 & 0.038 & -0.207 & 0.112 & 0.037 & 0.021 \\
\hline Supplemental Security Income & -0.162 & 0.017 & -0.826 & 0.054 & -0.023 & 0.009 \\
\hline SSI and SSDI & -0.004 & 0.021 & 0.124 & 0.088 & -0.031 & 0.011 \\
\hline \multicolumn{7}{|l|}{ Living arrangements: } \\
\hline Community & 0.115 & 0.025 & -0.376 & 0.118 & - & - \\
\hline Residential & -0.093 & 0.027 & -0.022 & 0.091 & - & - \\
\hline Family income main support & 0.030 & 0.021 & 0.477 & 0.050 & - & - \\
\hline County unemployment rate & -0.067 & 0.003 & 0.084 & 0.010 & -0.002 & 0.002 \\
\hline District-level instrument & - & - & -0.142 & 0.005 & - & - \\
\hline Constant & 0.363 & 0.072 & 11.515 & 0.508 & 3.125 & 0.039 \\
\hline$\overline{\sigma_{1}^{2}}$ & 0.472 & 0.003 & & & & \\
\hline$\rho_{12}$ & 0.139 & 0.041 & & & & \\
\hline$\rho_{13}$ & -0.184 & 0.043 & & & & \\
\hline$\rho_{23}$ & -0.005 & 0.070 & & & & \\
\hline $\mathrm{N}$ & 38,195 & & & & & \\
\hline$\Lambda$ & $-40,556$ & & & & & \\
\hline
\end{tabular}


Table A2.3. Results from Joint Estimation of Successful Case Closure, Benefit Counseling and Weekly Earnings Equations

\begin{tabular}{|c|c|c|c|c|c|c|}
\hline \multirow[b]{2}{*}{ Variables } & \multicolumn{2}{|c|}{ Successful case closure } & \multicolumn{2}{|c|}{ Benefit counseling } & \multicolumn{2}{|c|}{ Earnings } \\
\hline & Coeff. & SE & Coeff. & SE & Coeff. & SE \\
\hline Benefit counseling & 0.183 & 0.152 & - & - & 0.395 & 0.090 \\
\hline \multicolumn{7}{|l|}{ Disability type: } \\
\hline Sensory & 0.337 & 0.032 & -0.326 & 0.104 & 0.050 & 0.022 \\
\hline Mental & 0.050 & 0.017 & 0.027 & 0.046 & -0.238 & 0.012 \\
\hline Secondary disability & -0.113 & 0.013 & 0.145 & 0.041 & -0.057 & 0.010 \\
\hline Married & 0.110 & 0.021 & -0.072 & 0.055 & 0.099 & 0.014 \\
\hline Age & 0.010 & 0.004 & -0.012 & 0.011 & -0.001 & 0.002 \\
\hline $\operatorname{Age}^{\wedge} 2$ & -0.015 & 0.005 & 0.007 & 0.014 & -0.008 & 0.003 \\
\hline \multicolumn{7}{|l|}{ Race group: } \\
\hline Black & -0.087 & 0.016 & -0.020 & 0.049 & 0.188 & 0.011 \\
\hline Hispanic & -0.063 & 0.022 & -0.074 & 0.082 & 0.246 & 0.016 \\
\hline Asian & -0.118 & 0.054 & -0.017 & 0.196 & 0.074 & 0.039 \\
\hline Other & -0.073 & 0.037 & 0.267 & 0.092 & 0.027 & 0.026 \\
\hline Male & 0.057 & 0.013 & -0.069 & 0.039 & 0.070 & 0.009 \\
\hline \multicolumn{7}{|l|}{ Education: } \\
\hline HS diploma & -0.071 & 0.017 & 0.134 & 0.052 & 0.217 & 0.012 \\
\hline Some college & -0.096 & 0.019 & 0.148 & 0.058 & 0.349 & 0.014 \\
\hline College+ & 0.073 & 0.026 & 0.028 & 0.077 & 0.540 & 0.018 \\
\hline Veteran & -0.070 & 0.038 & -0.206 & 0.112 & 0.049 & 0.028 \\
\hline Supplemental Security Income & -0.163 & 0.017 & -0.827 & 0.054 & -0.081 & 0.012 \\
\hline SSI and SSDI & -0.006 & 0.021 & 0.128 & 0.088 & -0.065 & 0.015 \\
\hline \multicolumn{7}{|l|}{ Living arrangements: } \\
\hline Community & 0.158 & 0.025 & -0.381 & 0.118 & - & - \\
\hline Residential & -0.086 & 0.027 & -0.027 & 0.092 & - & - \\
\hline Family income main support & 0.029 & 0.021 & 0.478 & 0.050 & - & - \\
\hline County unemployment rate & -0.067 & 0.003 & 0.085 & 0.010 & 0.007 & 0.003 \\
\hline District-level instrument & - & - & -0.140 & 0.005 & - & - \\
\hline Constant & 0.371 & 0.072 & 11.384 & 0.507 & 5.115 & 0.052 \\
\hline$\overline{\sigma_{1}^{2}}$ & 0.626 & 0.007 & & & & \\
\hline$\rho_{12}$ & 0.302 & 0.048 & & & & \\
\hline$\rho_{13}$ & -0.167 & 0.064 & & & & \\
\hline$\rho_{23}$ & -0.024 & 0.072 & & & & \\
\hline $\mathrm{N}$ & 38,195 & & & & & \\
\hline$\Lambda$ & $-45,365$ & & & & & \\
\hline
\end{tabular}




\section{RECENT WORKING PAPERS FROM THE CENTER FOR RETIREMENT RESEARCH AT BOSTON COLLEGE}

How Do the Changing Labor Supply Behavior and Marriage Patterns of Women Affect Social Security Replacement Rates?

April Yanyuan Wu, Nadia S. Karamcheva, Alicia H. Munnell, and Patrick Purcell, July 2013

Social Security and the 2001 Reform of the Railroad Retirement Program

Steven A. Sass, June 2013

An Assessment of the 2001 Reform of the Railroad Retirement Program

Steven A. Sass, June 2013

Reforming the Railroad Retirement System

Steven A. Sass, June 2013

How Do the Disabled Cope While Waiting for SSDI?

Norma B. Coe, Stephan Lindner, Kendrew Wong, and April Yanyuan Wu, June 2013

The Impact of Population Aging and Delayed Retirement on Workforce Productivity Gary Burtless, May 2013

Does Access to Health Insurance Influence Work Effort Among Disability Cash Benefit Recipients?

Norma B. Coe and Kalman Rupp, April 2013

How Will Older Workers Who Lose Their Jobs During the Great Recession Fare in the Long-Run?

Matthew S. Rutledge, Natalia Orlova, and Anthony Webb, March 2013

Can Long-Term Care Insurance Partnership Programs Increase Coverage and Reduce Medicaid Costs?

Wei Sun and Anthony Webb, March 2013

SSI for Disabled Immigrants: Why Do Ethnic Networks Matter?

Delia Furtado and Nikolaos Theodoropoulos, February 2013

The Use of VA Disability Benefits and Social Security Disability Insurance Among Veterans

Janet M. Wilmoth, Andrew S. London, and Colleen M. Heflin, February 2013

All working papers are available on the Center for Retirement Research website (http://crr.bc.edu) and can be requested by e-mail (crr@bc.edu) or phone (617-552-1762). 